\title{
The impact of the financial-economic crisis on sustainability transitions: Financial investment, governance and public discourse
}

\author{
Frank W. Geels \\ Sustainable Consumption Institute (SCI) \& Manchester Institute of Innovation Research (MIoIR), \\ University of Manchester, United Kingdom
}

\section{A R T I C L E I N F O}

\section{Article history:}

Received 27 September 2012

Received in revised form 23 November

2012

Accepted 23 November 2012

Available online 20 December 2012

\section{Keywords:}

Crisis

Finance

Governance

Public attention

Sustainability transitions

\begin{abstract}
A B S T R A C T
The paper distinguishes four views on the impact of the financialeconomic crisis on sustainability transitions (operationalized as diffusion of green niche-innovations). The first three views highlight the possibility of positive impacts of the financial-economic crisis on sustainability transitions and joint solutions: (a) a comprehensive transformation of the capitalist system, (b) a green Industrial Revolution, linked to a sixth green Kondratieff wave, and (c) green growth. The fourth view perceives the impact as mainly negative, because the financial-economic crisis weakens public, political and business attention for environmental problems. The paper confronts these views with secondary data on three analytical categories: (1) financial investment, (2) policy and governance, and (3) public opinion and civil society. Data focus on renewable energy and climate policy in the UK, Europe and the world. The paper concludes that the early crisis years (2008-2010) created a window of opportunity for positive solutions. But since 2010-2011 this window appears to be shrinking, with the financial-economic crisis having negative influences on sustainability transitions that may cause some slow-down.
\end{abstract}

(c) 2012 Elsevier B.V. All rights reserved.

\section{Introduction}

Many (Western) countries face difficult times. Firstly, there is the immediate financial crisis, related to deflation of the housing bubble, the collapse of the banking system, and (private and

E-mail addresses: frank.geels@mbs.ac.uk, f.w.geels@sussex.ac.uk 
sovereign) debt. Secondly, there are medium-term (5-10 years) socio-economic problems related to high unemployment, growing inequality, austerity programmes, welfare cutbacks, and weak industrial competitiveness in a globalized world. And thirdly, there are long-term (10-50 years) environmental problems (climate change, biodiversity loss, ocean acidification, chemical pollution, freshwater water and land use problems), which are transgressing planetary boundaries (Rockström et al., 2009).

With regard to these environmental problems, a new scientific research stream has emerged, which argues that addressing them requires large-scale sustainability transitions in socio-technical systems related to transport, energy and agri-food (Smith et al., 2010; Van den Bergh et al., 2011; Markard et al., 2012). A particular perspective in this research stream is the multi-level perspective (Geels, 2002; Van Bree et al., 2010), which conceptualizes sustainability transitions as green niche-innovations struggling against existing (unsustainable) systems, and potentially replacing or reconfiguring these systems (Geels and Schot, 2007). Some green niche-innovations (e.g. organic food, hybrid-electric vehicles, wind turbines, bio-energy) may be entering a take-off phase in some countries (see Section 2).

In relation to existing transition research, this paper aims to make two contributions. The first contribution is to widen the analytical focus to include the current financial and economic crisis. In the current socio-economic context, it seems somewhat narrow to focus only on the environmental problems, as many papers in the transitions literature do. As a first step towards this wider agenda, this paper investigates the impacts of the financial-economic crisis on sustainability transitions, in particular on the emergence and diffusion of green niche-innovations. The second contribution is to (gradually) shift the analytical focus from the emergence of niche-innovations to their diffusion and take-off. Much of the transition literature implicitly assumes that green niche-innovations are small and need protection. While this is still true for many niche-innovations, it no longer applies across the board, as some green niche-innovations are entering mainstream markets in some countries. This take-off phase brings with it new challenges, which are discussed in Section 2.2.

The paper's main emphasis is on the first contribution, i.e. investigating the impact of the financial-economic crisis on sustainability transitions. This is not an easy topic, because crises are by definition confusing and contested phenomena, which challenge existing ways of doing and understanding. Crises can disrupt existing institutions and cause uncertainty about future directions, which offers opportunities for substantial change that deviates from locked-in trajectories. Whether or not these opportunities are taken depends on how (causes and solutions) of crises are interpreted. Crises are not self-apparent phenomena, but need to be narrated and explained. During periods of uncertainty, multiple interpretations compete with each other, and the likelihood of institutional change depends on which narrative becomes dominant. Blyth (2002) articulated this view, and illustrated it with two case studies of economic crises in the 1930s and 1970s, which both ushered in major institutional changes. He argues that ideas, discourses and narratives are important in crises: "At these junctures, it is ideas that tell agents what to do and what future to construct" (p. 11).

With regard to the contemporary crisis, I distinguish four different narratives and interpretations. These four views, which do not necessarily contradict each other and partly overlap, offer somewhat different appreciations of relations between the financial-economic crisis and environmental problems. The first two views interpret both causes and (possible) solutions, whereas the last two mainly focus on the way forward.

The first view perceives the financial-economic crisis and environmental problems as symptoms of deeper cultural problem in modern capitalist societies, e.g. obsession with growth (Jackson and Victor, 2011), exploitation of nature, dominance of financial capitalism (Wray, 2009) and debt-fuelled consumption. In this interpretation, modern societies have entered a special historical era in which financial, socio-economic and environmental problems converge into a 'triple crisis'. The triple crisis, which signals the possibility of planetary breaking points, can have positive effects on sustainability transitions if we recognize its deeper cultural and structural roots. This recognition may then pave the ground for fundamental solutions such as a zero-growth economy (or even de-growth), redistribution of work and time, redistribution of income and wealth, and a focus on happiness rather than GDP (Gough, 2010). Addressing the triple crisis may also require a shift to more services (e.g. mobility services, energy services, recycling, re-using, leasing) and radical niches. "The seeds for such an economy may already exist in thriving local or community-based social enterprises: community energy 
projects, local farmers markets, slow food cooperatives, sports clubs, libraries, community health and fitness centres, community music and drama, local training and skills, hairdressing, gardening and conservation" (Jackson and Victor, 2011: 104).

The second view sees the financial-economic crisis as related to (Kondratieff) long-wave dynamics. Proponents of this view build on the work of Freeman and Perez (1988) and Perez (2002), who distinguish five long waves (techno-economic paradigm shifts) in the last 200 years, which were driven by new pervasive technologies. During the 'installation period', when these new technologies emerge in specific sectors, dynamics tend to be by driven financial capital and speculative investment. Wider diffusion of pervasive technologies is often hindered by a mis-match with the wider socio-institutional framework. A shift to a wider 'deployment' therefore tends to be accompanied by socio-economic crises (Perez, 2002), which are followed by institutional adjustments that enable the new technology to reach its full potential. So, socio-economic crises are seen as a normal, even necessary, part of broad transitions. The current crisis is interpreted as signalling the shift from the 'installation phase' of the ICT-paradigm to the 'deployment phase' which requires the disciplining of finance and its reorientation towards productive, long-term investments in the real-economy (Perez, 2009; Gore, 2010; see also Perez in this special issue). Extrapolating these ideas into the future, authors (Bradfield-Moody and Nogrady, 2010; Allianz Global Investors, 2010; Gore, 2010) have proposed that the current crisis also signals the 'installation period' of a sixth green wave, carried by renewable energy, resource efficiency, green nanotechnology, and green chemistry. The convergence of the ICT-paradigm and the green Industrial Revolution may offer a way out of the current crisis (see Perez in this special issue). So, this view suggests that the financial-economic crisis may have a positive effect on sustainability transitions. In fact, the crisis may form the tipping point towards the next green wave (if finance can be disciplined and reoriented in green directions).

A potential problem in this view is the implicit determinism in the metaphor of successive 'waves', which suggests an inevitable internal logic. ${ }^{1}$ To restore agency and the importance of policy change, some theorists therefore argue that the financial-economic crisis only creates opportunities for a sustainability transition which need to be taken by actors: "Getting into the upswing will not be automatic and will require policy and institutional changes which are much more far-reaching than those already undertaken or even now being contemplated" (Gore, 2010: 725).

A third view, which focuses less on the causes of the crisis and more on a possible way forward, is the discourse on 'green growth' or 'transition to a green economy' (UNEP, 2009, 2011; OECD, 2011). Green growth is a new strategic narrative that promises to solve both environmental and economic problems. It frames environmental protection in terms of opportunity and reward rather than additional costs. There are different perspectives on green growth with different degrees of ambition (Bowen and Fankhauser, 2011): (a) green growth can be economic growth that is slightly greener; associated policy measures are green taxes that address negative externalities (and thus improve well-being), (b) green growth can be the creation of new jobs in green sectors; associated policy measures are public spending on green investments (Keynesian 'green stimulus') that stimulates aggregate demand; (c) green growth can arise from a green Industrial Revolution ${ }^{2}$; this requires investments in new technologies, markets, skills, infrastructures, and broad socio-institutional change. So, all forms of green growth require substantial policy change.

A fourth view is that the financial-economic crisis and environmental problems are different in terms of time-frames, causes and solutions and that they are competing with each other for political and societal attention. The financial-economic crisis may hinder sustainability transitions by changing social and political priorities and eroding investor confidence. Ashford et al. (2012: 2), for instance, argue that: "for the foreseeable future, unemployment and underemployment (the under-utilization of the skills and productive potential of employed labor) are likely to dominate political concerns and debate". Gough and Meadowcroft (2011: 494) also suggest that fiscal and economic problems have returned as central political issues, and warn that this may hinder or delay sustainability transitions: "The real worry is that a serious mitigation response will be delayed for one or more decades." In a

\footnotetext{
1 Perez (2002) has developed a more nuanced and less deterministic version.

2 This perspective overlaps with the second view.
} 


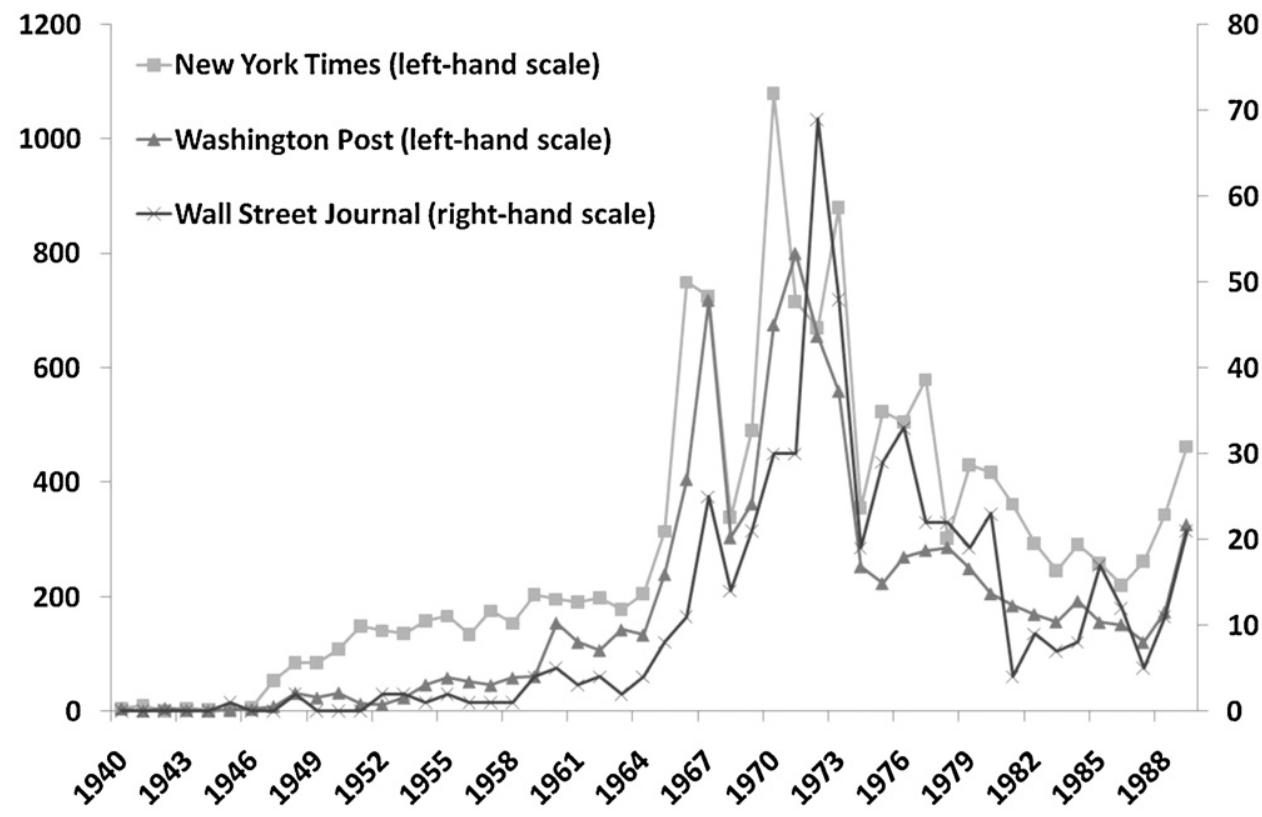

Fig. 1. Public attention to air pollution in the US, represented by the yearly number of articles in national newspapers (Penna and Geels, 2012: 1005). (The graph is based on data from a keyword search in the digital archives of these newspapers. 'Air pollution' and 'smog' were used as keywords. Duplicated articles were excluded.)

historical study of air pollution, Penna and Geels (2012) found that the 1973 oil crisis and ensuing recession caused a steep decrease in public attention to the issue (Fig. 1), followed by stagnation in the implementation of the 1970 Clean Air Act. The 1979 oil crisis and the recession of the early 1980s caused a further decline in attention and stalled political action on air pollution until 1990. So, historical evidence provides some indications of negative relations between economic crises and attention to environmental problems.

This fourth view does not imply that the sustainability transition will be permanently halted (because persistent environmental problems will not disappear). But it does accept that transitions are non-linear processes, which may move backwards as well as forward. Comparing the creation of a welfare state with a possible transition to an 'eco-state', Meadowcroft (2005) concludes that "during the evolution of welfare states, periods of rapid growth or innovation alternated with phases of consolidation or stagnation. The development of welfare states was not smooth, but uneven and episodic". This non-linear dynamic implies that the current economic crisis may cause setbacks in sustainability transitions.

The first three views highlight the possibility of positive impacts of the financial-economic crisis on sustainability transitions and a joint solution, although for somewhat different reasons: (a) the triple crisis can be a cataclysmic event that forces recognition of deeper cultural and structural roots, and implementation of radical solutions, (b) the financial-economic crisis may lead to socio-political protest for institutional reform, and (c) the financial-economic crisis may trigger a shift to a new (green) growth path. The fourth view, however, perceives the impact as mainly negative.

The proposition in this paper is a temporal mix of these views. I suggest that the early crisis years (2008-2010) created a window of opportunity in which solutions for the economic problem (e.g. green stimulus packages) may have accelerated the take-off of certain green niche-innovations. But since 2010-2011, this window may be shrinking, as the financial-economic crisis influences public 


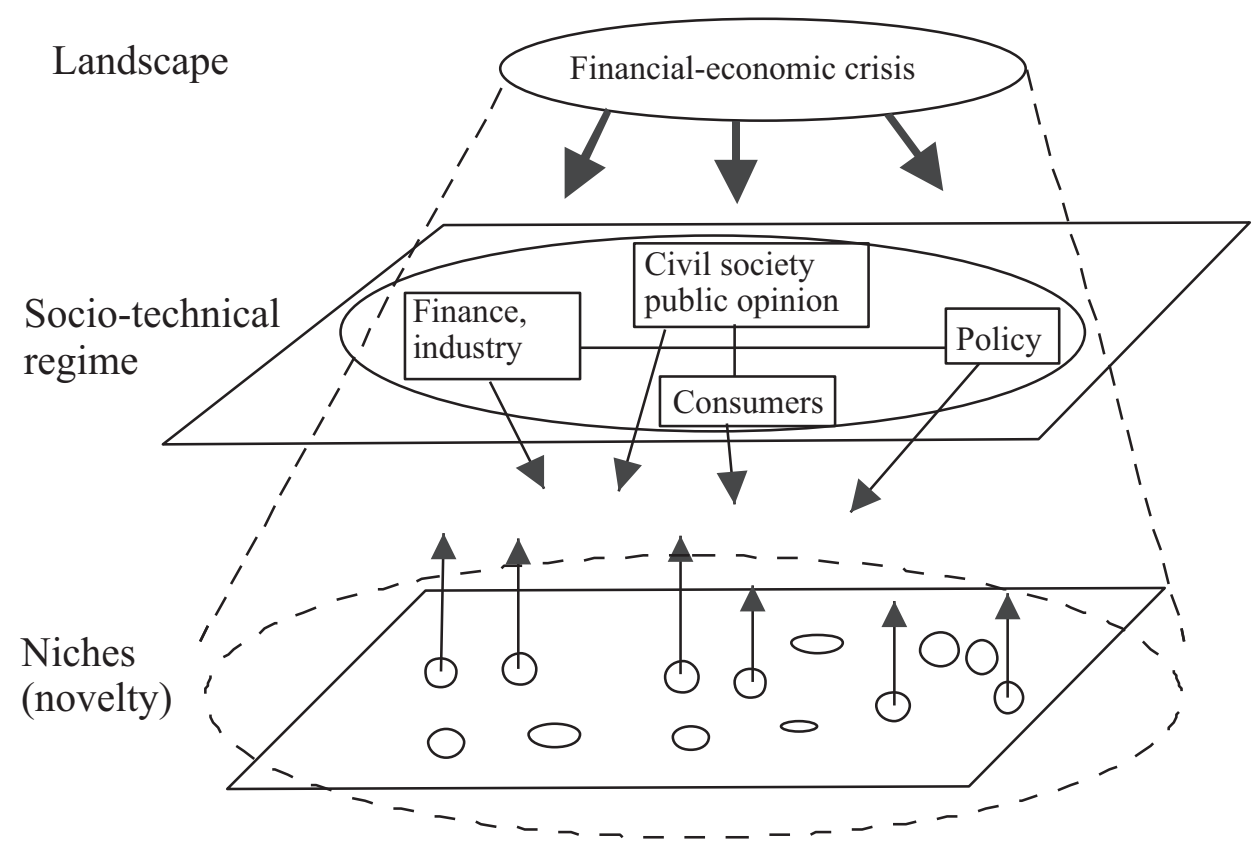

Fig. 2. Green niche-innovations struggling against dimensions of the existing regime in the context of influences from the financial-economic crisis.

discourse, governance, and financial investment in ways that hinder sustainability transitions. ${ }^{3}$ To assess this proposition empirically, Section 3 of this paper presents secondary data on three analytical categories: financial investment, policy and governance, public opinion and civil society. For finance, I will focus on the energy domain, specifically on global investments in renewable energy in the last few years. The section on governance addresses the international level (green stimulus, climate change negotiations), Europe (emissions trading), UK (public R\&D investments, green investment bank), and city level (green urban initiatives). For public opinion and civil society I focus mainly on the UK. Before delving into the empirical assessments, the next section provides some empirical and conceptual considerations about the current stage of sustainability transitions. The paper ends with conclusions in Section 4.

\section{Initial empirical and conceptual considerations of sustainability transitions}

In terms of the multi-level perspective (Geels, 2002; Geels and Schot, 2007), the research question can be conceptualized as follows (Fig. 2). The financial-economic crisis can be seen as a shock at the landscape level. This shock creates pressures on regimes in concrete empirical domains (food, mobility, energy), where it may affect investor confidence, availability of capital, public concerns, and the political will to act in favour of sustainability. At the niche-level there are many green innovations that struggle against existing regimes. The wider diffusion of these niche-innovations may require changes in the socio-technical regime, e.g. changes in consumer practices, changes in public policies to favour green options (e.g. carbon tax, stricter environmental regulations, green infrastructure investments), reorientations of incumbent firms and investors (using their resources to develop, market

\footnotetext{
${ }^{3}$ This is a broad assessment, and I acknowledge that there may be sectoral and geographical variation. Germany's Energiewende and Japan's plans for renewables, both in response to the Fukushima nuclear disaster (March 2011), are positive developments, for instance, although there are worries that the gaps created by phasing out nuclear energy may be filled with coal and gas-powered plants rather than renewables.
} 
Table 1

Changes in market share for organic food in selected European countries (\%) (Oosterveer and Spaargaren, 2012: 140). ${ }^{\mathrm{a}}$

\begin{tabular}{lllll}
\hline & 1997 & 2003 & 2005 & 2007 \\
\hline Germany & 1.2 & 2.2 & 3.0 & 3.1 \\
Italy & 0.5 & 1.5 & 1.6 & NA \\
United Kingdom & 0.4 & 1.7 & 2.3 & NA \\
France & 0.4 & NA & 1.1 & 1.2 \\
Switzerland & 2.0 & NA & 4.5 & 4.6 \\
Netherlands & NA & 1.0 & 1.8 & 2.0 \\
\hline
\end{tabular}

NA: not available.

${ }^{a}$ In one of the leading countries, Austria, 7.4\% of all food products sold in supermarkets (including discount stores) were organic in 2011 (http://typischich.at/home/gesundheit/ernaehrung/692943/BioTrend).

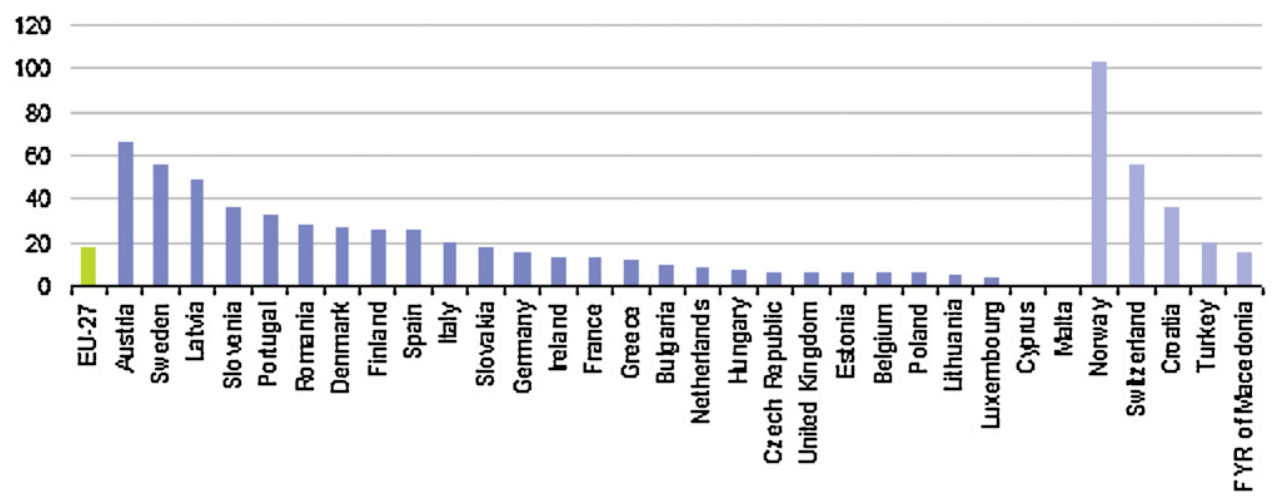

Fig. 3. Proportion of electricity generated from renewable sources, 2009 (\% of gross electricity consumption) (Eurostat).

and implement green options), and changes in public discourse. Without such regime changes, green niche-innovations may continue to face uphill struggles and uneven playing fields. So, the question is how these multi-level interactions influence sustainability transitions. The two subsequent sections further unpack this question. Section 2.1 suggests that some green niche-innovations have entered a take-off stage. Section 2.2 conceptually elaborates some of the wider regime challenges associated with this take-off phase.

\subsection{Entering the take-off phase in sustainability transitions}

After a decades-long emergence process, some green niche-innovations are gathering momentum in certain countries. Sustainability transitions may therefore be entering a new phase, moving from a pre-development phase (with an emphasis on R\&D and experimentation) to a take-off phase (with more emphasis on real-world deployment and installation of green solutions). In the agri-food sector, for instance, the niche-innovation of organic food has gathered pace (Table 1).

In the energy sector, renewable energy has a share of $9 \%$ of primary energy in the European Union, with several countries scoring much higher (Norway, Sweden, Austria) and lower (UK, Netherlands, Malta) (Table 2). For electricity, the European share of renewable power is higher, about $18 \%$ in 2009 (Fig. 3).

In the US transport sector, sales of various 'green' cars (Hybrid-Electric Vehicles, Plugin HybridElectric Vehicles, Extended Range Electric Vehicles and Battery-Electric Vehicles) peaked in 2007 (Fig. 4), reaching between 2 and 3\% of overall sales. ${ }^{4}$ Sales in Europe are lower, but also dominated by hybrid-electric vehicles.

${ }^{4}$ Precise numbers are $2.99 \%$ in $2007,2.37 \%$ in $2008,2.78 \%$ in $2009,2.37 \%$ in $2010,2.25 \%$ in 2011 , and $3.23 \%$ in 2012. 
Table 2

Share of renewables in gross inland energy consumption, EU and EU countries, 2009 (\%) (Eurostat).

\begin{tabular}{|c|c|c|c|c|c|c|}
\hline & Renewables total & Biomass and renewable wastes & Hydro & Geothermal & Wind & Solar \\
\hline EU-27 & 9.0 & 6.1 & 1.7 & 0.3 & 0.7 & 0.1 \\
\hline Euro area & 9.0 & 5.9 & 1.6 & 0.5 & 0.8 & 0.2 \\
\hline Norway & 42.4 & 4.5 & 37.6 & 0.0 & 0.3 & 0.0 \\
\hline Latvia & 36.2 & 29.2 & 6.9 & 0.0 & 0.1 & 0.0 \\
\hline Sweden & 34.4 & 21.6 & 12.3 & 0.0 & 0.5 & 0.0 \\
\hline Austria & 27.3 & 15.5 & 10.7 & 0.1 & 0.5 & 0.4 \\
\hline Finland & 23.2 & 19.9 & 3.2 & 0.0 & 0.1 & 0.0 \\
\hline Portugal & 19.0 & 12.6 & 2.9 & 0.7 & 2.6 & 0.2 \\
\hline Switzerland & 16.9 & 5.1 & 10.9 & 0.7 & 0.0 & 0.2 \\
\hline Denmark & 16.7 & 13.6 & 0.0 & 0.1 & 3.0 & 0.1 \\
\hline Romania & 14.9 & 11.0 & 3.8 & 0.1 & 0.0 & 0.0 \\
\hline Estonia & 13.5 & 13.2 & 0.1 & 0.0 & 0.3 & 0.0 \\
\hline Slovenia & 12.7 & 6.9 & 5.8 & 0.0 & 0.0 & 0.0 \\
\hline Croatia & 10.9 & 4.1 & 6.6 & 0.0 & 0.1 & 0.1 \\
\hline Lithuania & 10.5 & 9.8 & 0.4 & 0.1 & 0.2 & 0.0 \\
\hline Turkey & 9.9 & 4.6 & 3.1 & 1.6 & 0.1 & 0.4 \\
\hline Italy & 9.5 & 3.7 & 2.5 & 2.8 & 0.3 & 0.1 \\
\hline Spain & 9.3 & 4.5 & 1.7 & 0.0 & 0.3 & 0.0 \\
\hline Germany & 8.5 & 6.5 & 0.5 & 0.1 & 1.0 & 0.3 \\
\hline France & 7.5 & 5.3 & 1.9 & 0.0 & 0.3 & 0.0 \\
\hline Hungary & 7.3 & 6.7 & 0.1 & 0.4 & 0.1 & 0.0 \\
\hline Slovakia & 7.2 & 4.9 & 2.2 & 0.1 & 0.0 & 0.0 \\
\hline Poland & 6.6 & 6.2 & 0.2 & 0.0 & 0.1 & 0.0 \\
\hline Bulgaria & 6.2 & 4.2 & 1.7 & 0.2 & 0.1 & 0.0 \\
\hline Greece & 6.1 & 3.2 & 1.5 & 0.1 & 0.7 & 0.6 \\
\hline Czech Republic & 5.7 & 5.2 & 0.5 & 0.1 & 3.0 & 0.1 \\
\hline Ireland & 4.3 & 2.1 & 0.5 & 0.0 & 1.7 & 0.0 \\
\hline Netherlands & 3.9 & 3.3 & 0.0 & 0.0 & 0.5 & 0.0 \\
\hline Belgium & 3.9 & 3.6 & 0.0 & 0.0 & 0.1 & 0.0 \\
\hline Cyprus & 3.5 & 1.4 & 0.0 & 0.0 & 0.0 & 2.1 \\
\hline United Kingdom & 3.0 & 2.4 & 0.2 & 0.0 & 0.4 & 0.0 \\
\hline Malta & 0.0 & 0.0 & 0.0 & 0.0 & 0.0 & 0.0 \\
\hline
\end{tabular}

\subsection{Wider challenges in the take-off phase}

With some green niche-innovations entering the take-off phase of sustainability transitions in certain countries, new kinds of challenges will gain importance. Firstly, greater amounts of financial investment are needed to facilitate on-the-ground deployment of green options. Whereas government R\&D, complemented with some private equity and venture capital, tend to dominate in the pre-development phase, up-scaling and deployment in the take-off phase tend to draw on other types of finance such public equity markets, credit markets, mergers and acquisition, and government subsidies (Fig. 5). The challenge for sustainability transitions is to mobilize large sums of money, as Giddens (2009: 123) notes: "The role of businesses, small and large, is going to be absolutely crucial in responding to climate change, not least because they will have to supply a good deal of the funding and also pioneer new technologies". The availability of these types of finance is shaped by economic conditions, financial regulations, and investor confidence.

The second challenge in the take-off phase concerns changes in policy and institutional frameworks. In the pre-development phase green niche-innovations are sheltered, nurtured and protected from adverse regime conditions. But in the take-off phase, they face multi-dimensional struggles with incumbent regimes. On policy dimensions, the odds are often stacked against niche-innovations, because formal institutions have been adjusted to the needs of incumbent actors (Walker, 2000). Niche-innovations often face a 'mis-match' with existing institutions (Freeman and Perez, 1988). So, further breakthrough and wider diffusion depends on changes in policy and institutional frameworks. This is especially the case for transitions towards sustainability, which refers to collective goods (with associated free rider problems). Because private actors have no immediate incentive to address 


\section{Electric drive vehicle sales in the U.S. market}

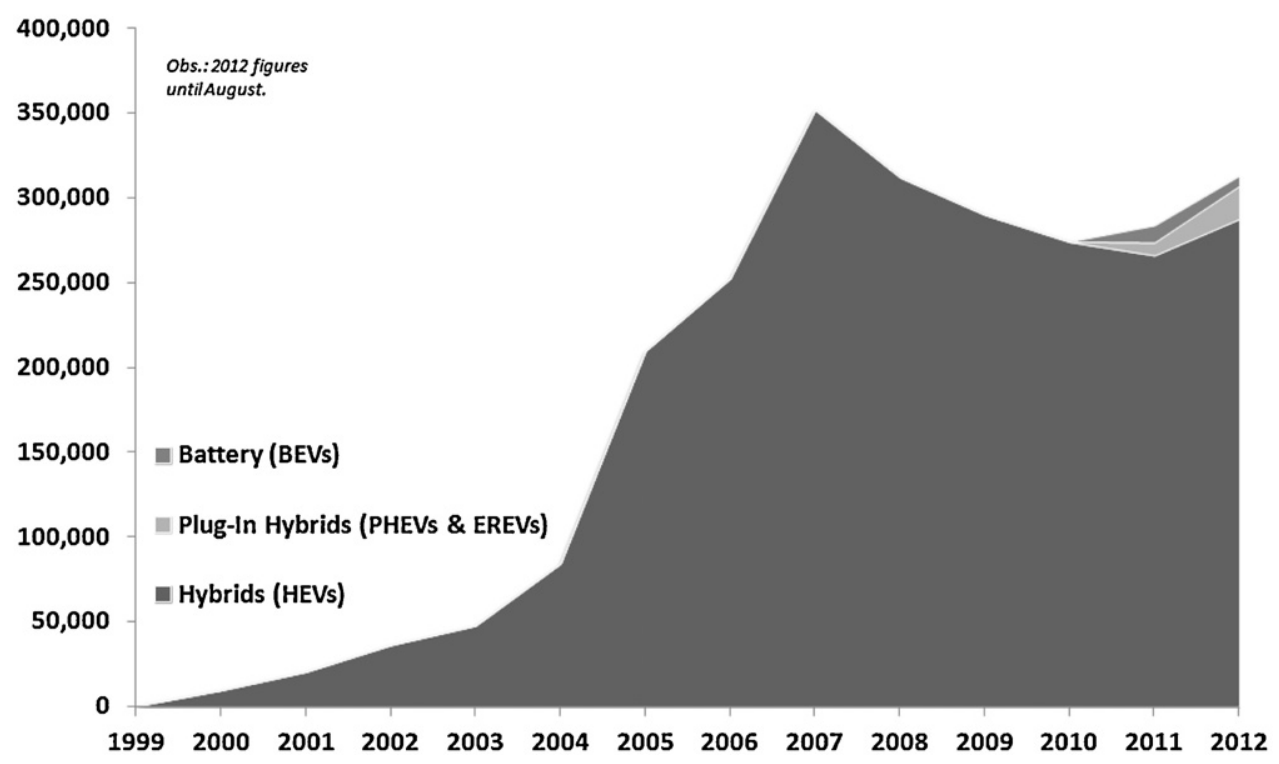

Fig. 4. Electric drive sales in the US market.

Source: Electric Drive Transport Association http://electricdrive.org/index.php?ht=d/sp/i/20952/pid/20952.

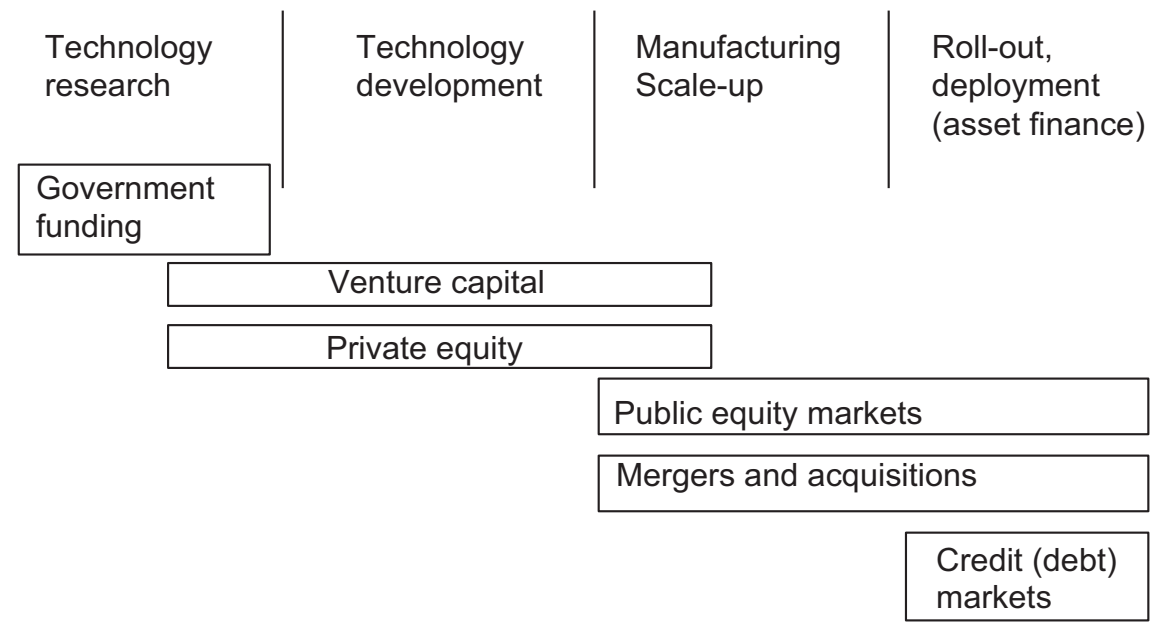

Fig. 5. Types of finance related phases of transitions (Frankfurt School, 2012: 10).

sustainability problems, public authorities have to change economic frame conditions and formal institutions (regulations, subsidies, incentives, taxes). That is why many green growth reports not only call for more investment, but also for stronger policies. UNEP (2011: 2), for instance, claims that: "there is a need for better public policies, including pricing and regulatory measures, to change the perverse market incentives that drive this capital mis-allocation. (...) To make the transition to a green economy, specific enabling conditions will be required. (...) At a national level, examples of such enabling conditions are: changes in fiscal policy; reform and reduction of environmentally harmful subsidies; employing new market-based instruments; targeting public investments to 'green' 
key sectors; greening public procurement; and improving environmental rules and regulations as well as their enforcement." The OECD (2011: 8) also argues for changes in fiscal and regulatory settings (such as tax and competition policy), innovation policy, environmental policies, which "include a mix of price-based instruments (for instance environmentally-related taxes) and non-market instruments such as regulations, technology support policies and voluntary approaches".

Making and implementing such institutional changes will be a difficult political process. Firstly, there is the normal problem of reluctance to change, related to institutional inertia and institutional path dependence (Pierson, 2000; Barbier, 2011). Secondly, there will be active resistance and lobbying from powerful incumbent interests aimed at hindering institutional change or creating loopholes that reduce the effectiveness of policies. Corporate interests have much influence as Levy and Newell (2000: 14) note: "The European commission undertakes business roundtables on a regular basis to consult with leading industrialists. The European Roundtable of Industrialists, made up of chief executive officers from 45 leading European companies, is arguably the most influential interest group in Brussels. (...) Although environmental groups may exercise influence in setting the agenda, when the point of decision is reached, large multinational companies and the organizations that represent them have key access to members of the commission, ministers, and heads of government in member states." As green innovations begin to compete with existing regimes, it is likely that incumbent players will flex their economic and political muscles even more to protect their interests. Following a useful distinction by Hall (1993), this political struggle will be played out at three levels:

(a) The precise setting of policy instruments; there will be struggles over the strictness of environmental regulations, height of carbon taxes etc.

(b) The kinds of policy instruments; many industries and policymakers have a preference for marketbased instruments rather that regulatory instruments, and have actively lobbied for the former in the last 10 years. But since some of these market-based instruments (e.g. European emissions trading) have not delivered what was promised, struggles may ensue about the implementation of other policy instruments.

(c) The overall goals that guide policies in particular fields and the associated belief systems (what Hall calls a policy paradigm). In the last few decades, many (Western) governments operated on the basis of a neo-liberal policy paradigm. Both the financial crisis and exacerbating environmental problems have given rise to doubts about the efficiency and capacity of markets to deliver with regard to public goods. Hence, there are pleas for changes in governance structures and a stronger role for governments in sustainability transitions. Scrase and MacKerron (2009: 232-233) claim that: "Market efficiency and driving down costs have their place, but governments must now become much more active in steering societies through the necessary transitions to a low carbon future." And Meadowcroft (2011: 71) argues that: "State intervention and governance reform are essential. To put this in another way: markets may drive the uptake of the iPhone (...), but they will not produce a carbon emission-free energy system (...). Changes to law - modifying the regulatory frameworks within which economic actors conduct their affairs (for example, by introducing a carbon tax of a GHG emissions cap and trade system) - and a significant expenditure of social revenue (for example, to accelerate development and deployment of new technologies and to ease societal adjustment to new patterns of production and consumption) are essential to encourage sustainability transitions."

The third challenge in the take-off phase entails securing wider public support and cultural legitimacy (Geels and Verhees, 2011). This is instrumentally important because "whatever can be done through the State will depend upon generating widespread political support from citizens" (Giddens, 2009: 91). Urgent demands from public opinion can offer politicians incentives to jockey for green agendas (Burnstein, 2003). Major policy shifts are therefore often accompanied by shifts in public opinion and cultural discourse, which, in turn, are shaped by social movements, media, industry associations, and special-interest groups (Hilgartner and Bosk, 1988). The literature on issue-attention cycles offers interesting ideas in this respect. The basic proposition is that social problems ('issues') have dynamics of their own and go through several phases. Concerns about social problems tend to emerge in civil society, then affect public opinion, subsequently spill over to political debates, and 


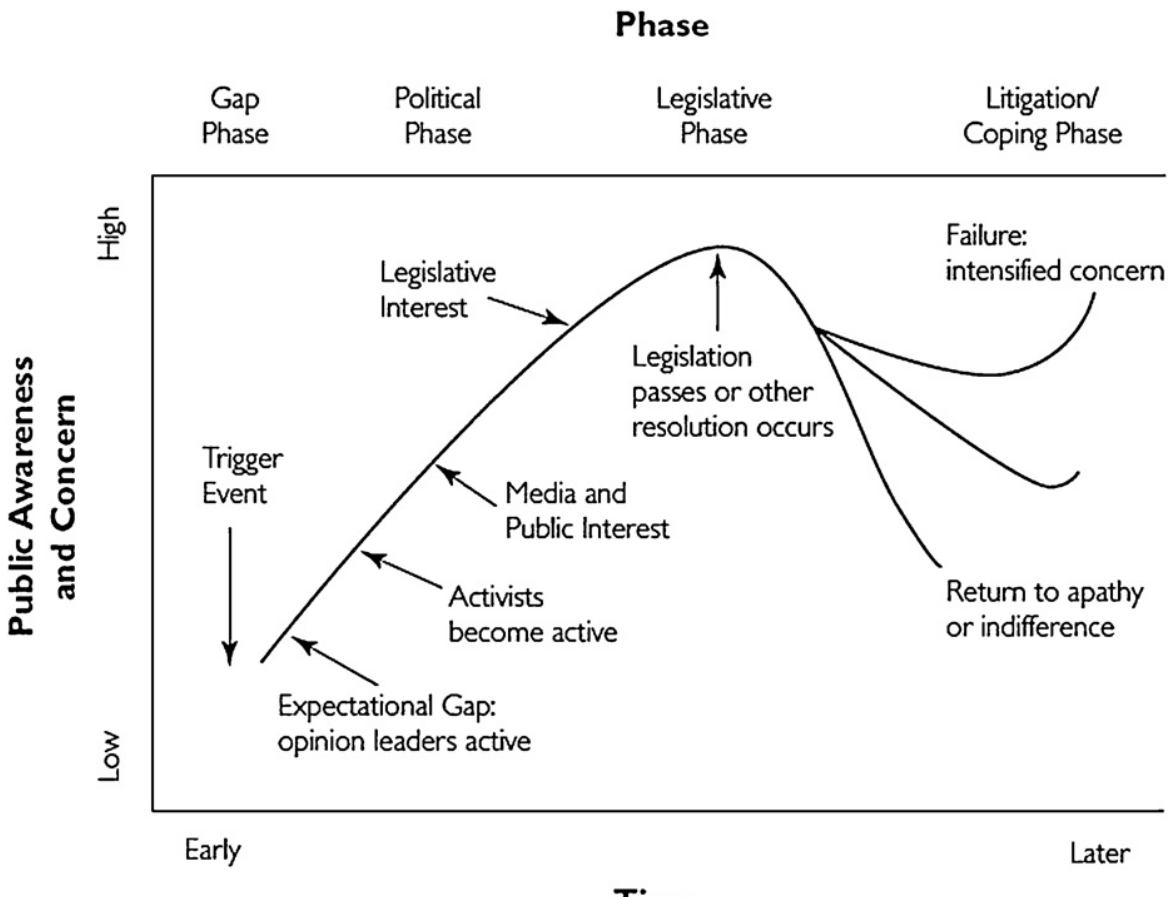

Time

Fig. 6. Temporal dynamics of issue lifecycles (Rivoli and Waddock, 2011: 91).

possibly lead to policies (Fig. 6). The introduction of substantive legislation often coincides with a peak in public concern (Y-axis in Fig. 6).

Issue-attention cycles do not necessarily progress linearly through all phase. Public attention and concern may also decline before substantive legislation is introduced. Downs (1972) warned that such declines may happen when publics realize that the costs of solving the problem are very high or may require sacrifices by large groups in the population. This realization may cause three reactions: "Some people just get discouraged. Others feel positively threatened by thinking about the problem; so they suppress such thoughts. Still others become bored by the issue" (p. 40). He also notes that attention to issues may decline because of competition with other prominent issues (see also Hilgartner and Bosk, 1988, who developed a conceptual model in which social problems compete for attention in public arenas). These considerations may be relevant for contemporary sustainability transitions, where the financial-economic crisis is potentially an issue that competes with sustainability concerns.

\section{Empirical analysis of the impact of the financial-economic crisis on green energy transitions}

The following three subsections aim to assess the influence of the financial-economic crisis on: (1) global finance for renewable energy, (2) green policies, climate policies, and urban initiatives, and (3) public opinion and civil society initiatives. Because of its broad scope, empirical data are less detailed than other studies using the multi-level perspective (e.g. Nykvist and Whitmarsh, 2008; Van Bree et al., 2010; Geels et al., 2012). Instead of looking at the beliefs, actions, and strategies of various social groups and the structural influences of rules of the game, this paper uses aggregate and (often) quantitative data from secondary sources. For financial data, Section 3.1 draws extensively on the impressive report by the Frankfurt School of Finance and Management (2012), prepared for UNEP in collaboration with 
Table 3

Global trends in renewable energy investment data, \$billion (Frankfurt School, 2012: 15).

\begin{tabular}{lrrrrrrrrr}
\hline & 2004 & 2005 & 2006 & 2007 & 2008 & 2009 & 2010 & $\begin{array}{c}2011 \\
\text { 2010-2011 } \\
\text { growth }\end{array}$ \\
\hline Venture capital & & & & & & & & & \\
Government R\&D & 0.4 & 0.6 & 1.2 & 2.1 & 3.0 & 1.5 & 2.4 & 2.5 & $5 \%$ \\
Corporate R\&D & 1.0 & 2.0 & 2.2 & 2.5 & 2.6 & 3.5 & 5.3 & 4.6 & $-13 \%$ \\
Private equity expansion capital & 5.1 & 2.5 & 2.9 & 2.7 & 3.9 & 4.0 & 4.6 & 3.7 & $-19 \%$ \\
Public markets & 0.3 & 1.0 & 3.0 & 3.2 & 6.9 & 2.8 & 2.9 & 2.5 & $-15 \%$ \\
Asset finance & 0.3 & 3.5 & 9.4 & 22.7 & 11.6 & 11.7 & 11.3 & 10.1 & $-10 \%$ \\
Small distributed capacity & 22.8 & 40.5 & 71.7 & 92.0 & 121.5 & 108.6 & 138.8 & 158.3 & $18 \%$ \\
Total & 8.6 & 10.8 & 7.2 & 13.4 & 21.6 & 31.2 & 60.4 & 75.8 & $25 \%$ \\
\hline
\end{tabular}

Bloomberg New Energy Finance. This report (hereafter referred to as Frankfurt School, 2012) focuses on global investments in renewable energy options such as wind, solar, biomass, waste-to-energy (w-t-e), small hydro, marine, and geo-thermal. Section 3.1 does not include various 'energy-smart' technologies that enhance the efficient use of electricity. ${ }^{5}$ For governance, Section 3.2 discusses various policy instruments and draws on assessments from renowned environmental policy analysts. Section 3.3 also addresses urban initiatives aimed at reconfiguring local (transport, energy) systems. For public opinion and attention, Section 3.3 draws on opinion polls and newspaper counts. The latter indicator is only a rough proxy (because it says little about how issues are discussed). Nevertheless Newig (2004: 159) suggests it is the best one available: "Assuming that in today's democracies the mass media constitute by far the most important vehicle for shared attention and political communication, media coverage, then, should best reflect public attention." Section 3.3 also touches on civil society initiatives that constitute more radical niche-innovations.

\subsection{Financial investment}

The general influence of the 2008 crisis has been a steep decline in business confidence, which translated into falling investments as a percentage of GDP. Fig. 7 represents this effect for the UK and United States, but similar trends characterize other developed countries. ${ }^{6}$

For renewable energy, however, the picture is more positive. Fig. 8 shows healthy growth in global investments from $\$ 39$ billion in 2004 to $\$ 257$ billion in 2011 .

Investment growth in Fig. 8 is mainly due to expansion in two financial categories: asset finance (for utility scale projects, larger than $1 \mathrm{MW}$ ) and small distributed capacity. ${ }^{7}$ Table 3 shows that most other investment categories (government $R \& D$, corporate $R \& D$, private equity, public markets) decreased from 2010 to 2011.

In terms of geography (Table 4), Europe remains the largest investor ( $\$ 101$ billion), followed by China ( $\$ 52.2$ billion) and United States ( $\$ 50.8$ billion). Growth in investments was particularly strong in the United States, where several incentive programmes (Federal loan guarantee programme, US Treasury grant programme, the Production Tax Credit) ended in late 2011 or early 2012. Developers rushed to finance projects before these programmes expired.

Below, I further discuss the following investment categories: (a) asset finance, (b) small distributed capacity, (c) government and corporate R\&D, and (d) venture capital and private equity.

\footnotetext{
${ }^{5}$ These 'energy-smart' options include the following categories: (a) smart meters, home energy management systems, (b) energy storage (batteries, fuel cells, flywheels), (c) energy efficiency innovations (heat pumps, insulation, light-emitting diodes), and (d) advanced transportation (electric and hybrid vehicles). Frankfurt School (2012) estimates global investment in these innovations at $\$ 18.9$ billion in 2011 , down $18 \%$ on 2010 .

${ }^{6}$ Recessions in the mid-1970s and early 1990s also caused major declines in UK fixed investments (Fig. 7).

7 Asset finance refers to all money invested in renewable energy generation projects, whether from internal company balance sheets, from loans, or from equity capital. Small distributed capacity (e.g. solar-PV on household rooftops) is financed differently (e.g. by property owners and public subsidies).
} 


\section{United Kingdom}

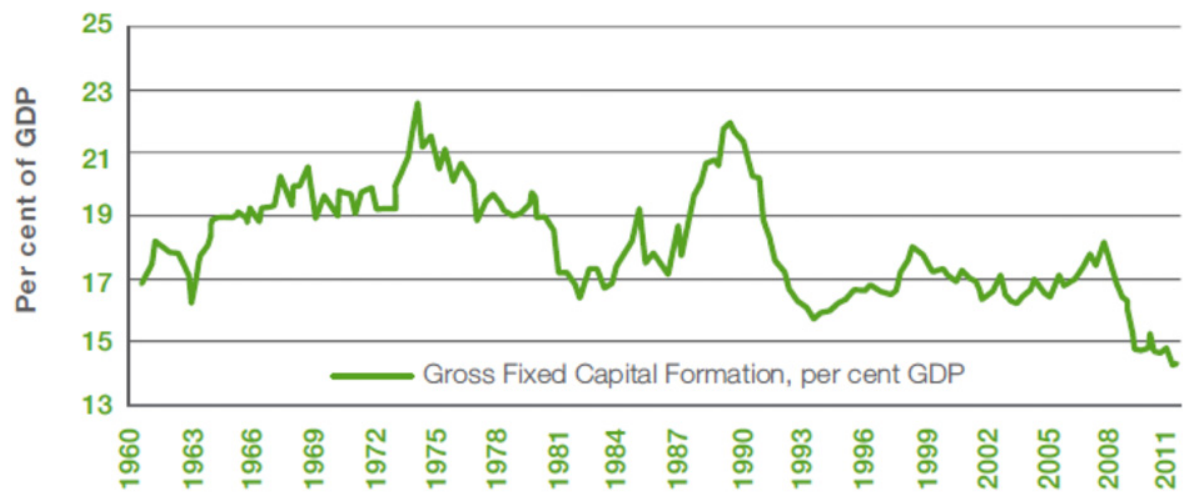

United States

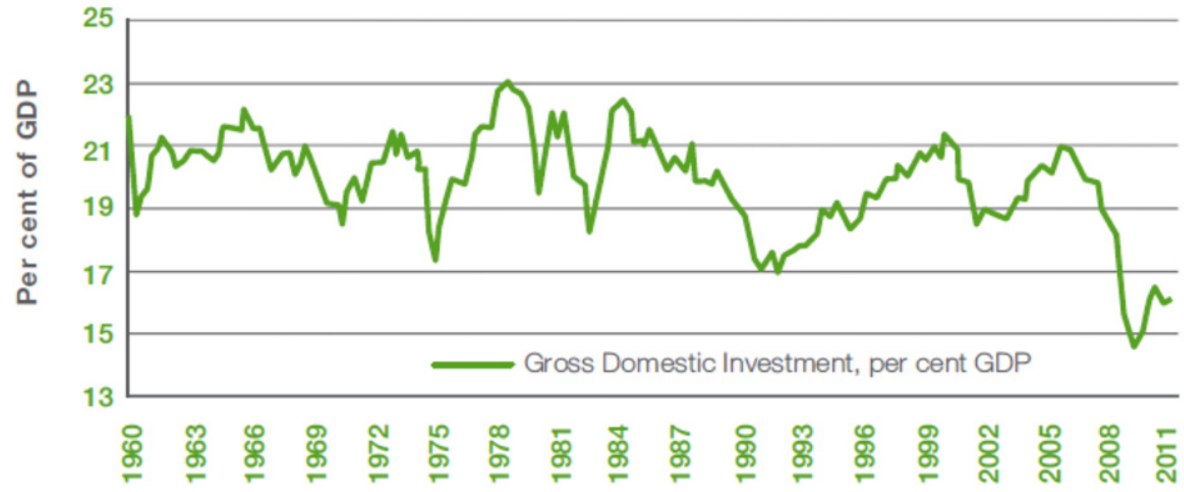

Fig. 7. Fixed investment (Zenghelis, 2012: 5; based on data from Bureau of Economic Analysis and Office of National Statistics).

Table 4

New investment by geography (Frankfurt School, 2012: 15).

\begin{tabular}{|c|c|c|c|c|c|c|c|c|c|}
\hline & 2004 & 2005 & 2006 & 2007 & 2008 & 2009 & 2010 & 2011 & $\begin{array}{l}\text { 2010-2011 } \\
\text { growth }\end{array}$ \\
\hline Europe & 18.6 & 27.7 & 37.4 & 57.8 & 67.1 & 67.9 & 92.3 & 101.0 & $10 \%$ \\
\hline United States & 7.4 & 11.2 & 27.2 & 28.5 & 37.7 & 22.5 & 32.5 & 50.8 & $57 \%$ \\
\hline China & 2.2 & 5.4 & 10.0 & 14.9 & 24.3 & 37.4 & 44.5 & 52.2 & $17 \%$ \\
\hline India & 2.0 & 2.9 & 4.7 & 5.6 & 4.7 & 4.2 & 7.6 & 12.3 & $62 \%$ \\
\hline ASOC (excl. China and India) & 7.2 & 8.0 & 8.0 & 10.1 & 11.0 & 12.1 & 18.4 & 21.1 & $15 \%$ \\
\hline Middle East and Africa & 0.3 & 0.4 & 1.6 & 1.9 & 3.7 & 3.1 & 6.7 & 5.5 & $-18 \%$ \\
\hline Brazil & 0.4 & 1.9 & 4.3 & 9.3 & 12.7 & 7.3 & 6.9 & 7.5 & $8 \%$ \\
\hline AMER (excl. US and Brazil) & 1.3 & 3.3 & 3.3 & 4.7 & 5.4 & 6.4 & 11.0 & 7.0 & $-36 \%$ \\
\hline Total & 39.5 & 60.8 & 96.5 & 132.8 & 166.6 & 160.0 & 219.8 & 257.5 & $17 \%$ \\
\hline
\end{tabular}

(a) Asset finance. Fig. 8 shows a dip in global investments in 2009, as a result of the financial crisis. In response to the crisis, governments across the globe responded with stimulus measures (fiscal and Keynesian investment) of around \$3.3 trillion. A substantial part was spent on 'green stimulus' packages, which boosted investment in the deployment of renewable energy, energy efficiency, 
Growth:
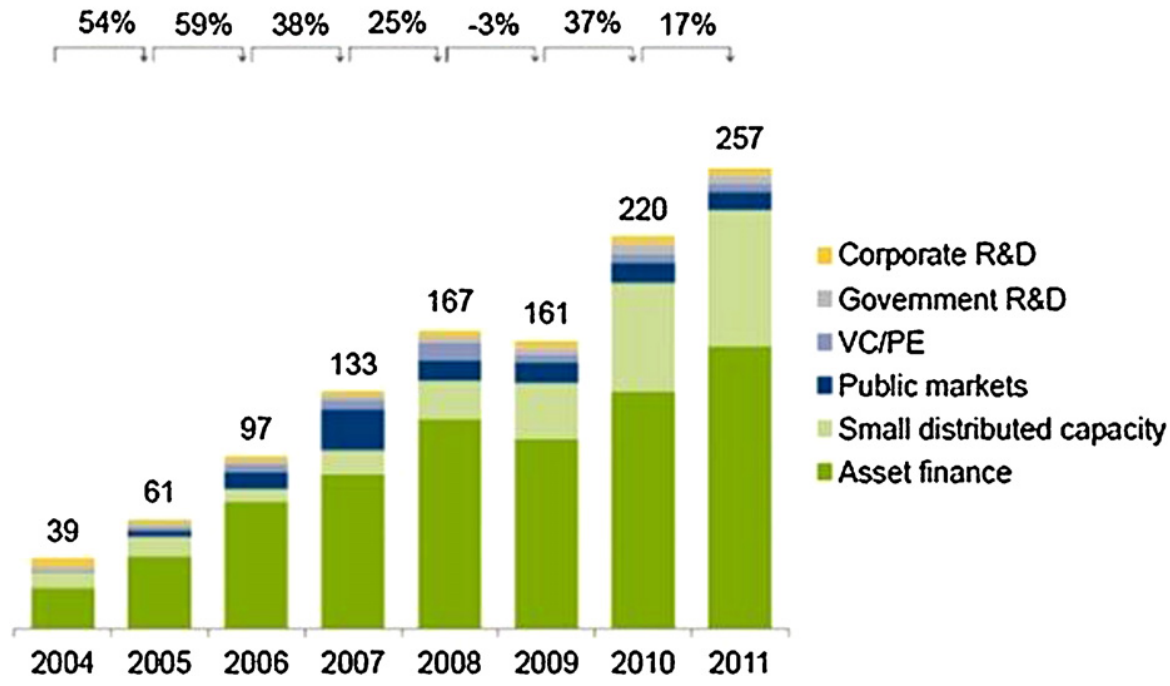

Fig. 8. Global new investment in renewable energy by asset class (in \$billion) (Frankfurt School, 2012: 13). (VE/PE refers to Venture Capital and Private Equity, which is all money invested by VC and PE funds in the equity of companies developing renewable energy technology.)

public transport and rail, and improving electrical grid transmission (Barbier, 2011). ${ }^{8}$ UNEP(2009) recommended an expenditure of $1 \%$ of global GDP as green stimulus. Countries responded differently to this recommendation, spending different amounts of their total stimulus packages on green innovations (Fig. 9). South Korea allocated $95 \%$ of its $\$ 38$ billion stimulus package to green investments, constituting 3\% of its GDP. China allocated about a third of its $\$ 647$ billion package to green investment, also about 3\% of its GDP (Barbier, 2010). The US spent about $12 \%$ of its $\$ 787$ billion package on green investment, about $0.7 \%$ of GDP. Germany and the UK spent respectively $13.2 \%$ and $6.9 \%$ of stimulus packages on green investment, amounting to $0.4 \%$ and $0.1 \%$ of GD (Edenhofer and Stern, 2009). In total, Barbier (2011) estimates that green stimulus packages amounted to $\$ 522$ billion, which boosted asset finance and deployment of green options.

In terms of specific technologies (Fig. 10), growth in asset finance (and small distributed capacity) was mostly driven by the expansion of solar power (61\%). ${ }^{9}$ Most other technologies (wind, biomass, biofuels, geothermal, marine) experienced shrinking investment. Most solar investments (55\%) went to small distributed capacity (rooftop PV-installations), and the remainder (45\%) to utilityscale projects (solar thermal plants, large-scale PV).

(b) Small distributed capacity. Germany and Italy dominated small-scale project investment (rooftop solar) in 2011, while the UK saw the fastest percentage growth (Fig. 11). Solar-PV expansion was driven by falling prices for PV-modules (almost 50\% in the year 2010-2011), and by generous subsidy schemes (feed-in tariffs), which were set to expire in 2012 and thus generated a rush of projects in 2011.

(c) Government and corporate RED. Global R\&D spending on renewable energy fell by $16 \%$ during 2011 to $£ 8.3$ billion (Fig. 12). R\&D spending was down across all technologies (Fig. 13).

Private sector R\&D spending fell across all regions (Fig. 14), which is worrying because it suggests that firms either face serious financial pressures or have less confidence in the future of green growth. Total government R\&D spending also fell, but Fig. 14 shows that this is mainly due to a

\footnotetext{
8 The 'green stimulus' was accompanied by a discourse on a Global Green New Deal (UNEP, 2009), and a discourse on green growth, which promised to address both economic and environmental problems.

${ }^{9}$ Solar water heaters are excluded, because they do not generate electric power.
} 


\section{GREEN INVESTMENTS}

Most G20 economies missed the Global Green

New Deal target of 1\% GDP (data as of July 2009).

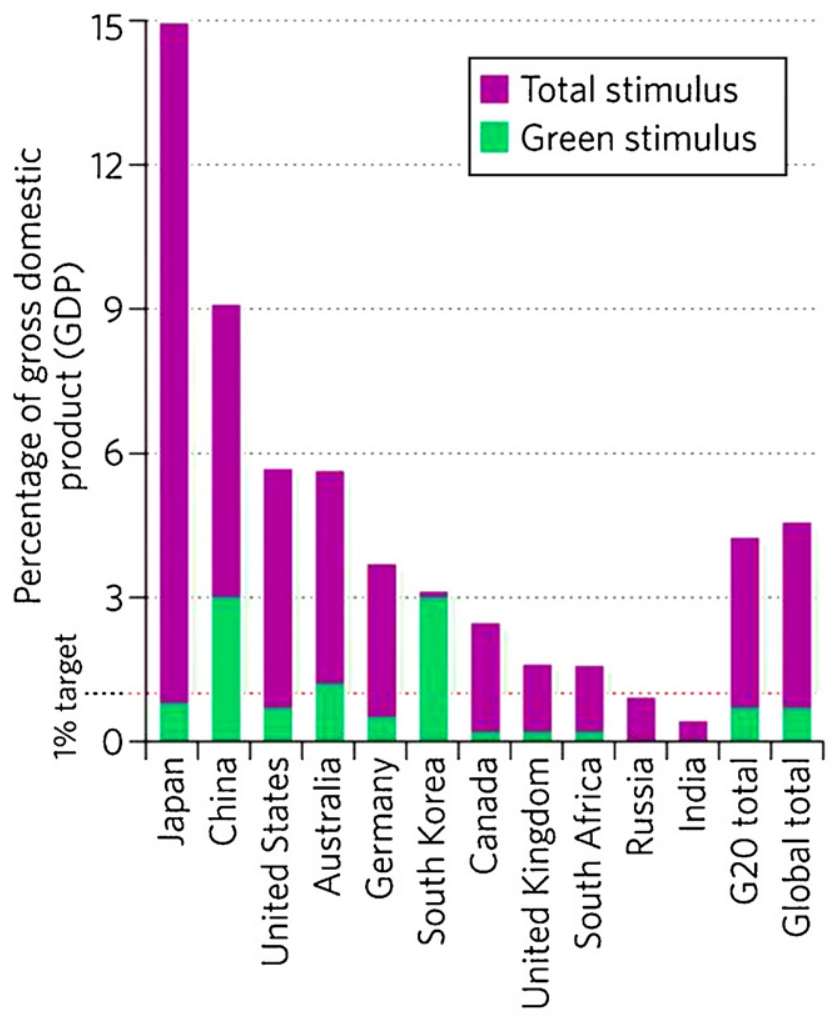

Fig. 9. Green investments relative to total stimulus packages, in \% of GDP (Barbier, 2010: 832).

sharp decline (66\%) in Asian countries such as Japan and Korea, where green stimulus packages announced in 2008-2009 began to unwind. Government R\&D in Korea was down 80\% (at \$132 million) and in Japan it was down 61\% (at \$212 million).

(d) Venture capital $(V C)$ and private equity (PE). The amount of money from this investment category (\$5 billion) is relatively small compared to overall investments in renewable energy ( $\$ 257.5$ billion). The total amount declined 6\% from 2010 to 2011 (Fig. 15). More importantly, there is a shift from risky early-stage VC to safer, and more incremental, late-stage investment. The former fell $21 \%$, while the latter increased $22 \%$. This suggests that investors are becoming more risk-averse because of market volatility, policy uncertainty, and competition from China. Yergin (2011) additionally suggests that there may be some disillusionment in the VC community. He reports that the VC community discovered energy and cleantech around 2003/2004 and that growing investments were based on the idea that VC would transform energy like it computers, Internet and ICT. But some years down the line venture capitalists are learning that energy is quite different from the digital world: "Energy has much longer lead times; it needs much more capital than the typical IT or software start-up, and then requires several subsequent rounds of capital injections, and its scale is much bigger. Projects need to be proved and then proved again at every stage. They may have to cope with unanticipated delays and substantial cost increases. (...) In short, significant changes in energy do not necessarily happen in the three-to-five-year time span that suits the 


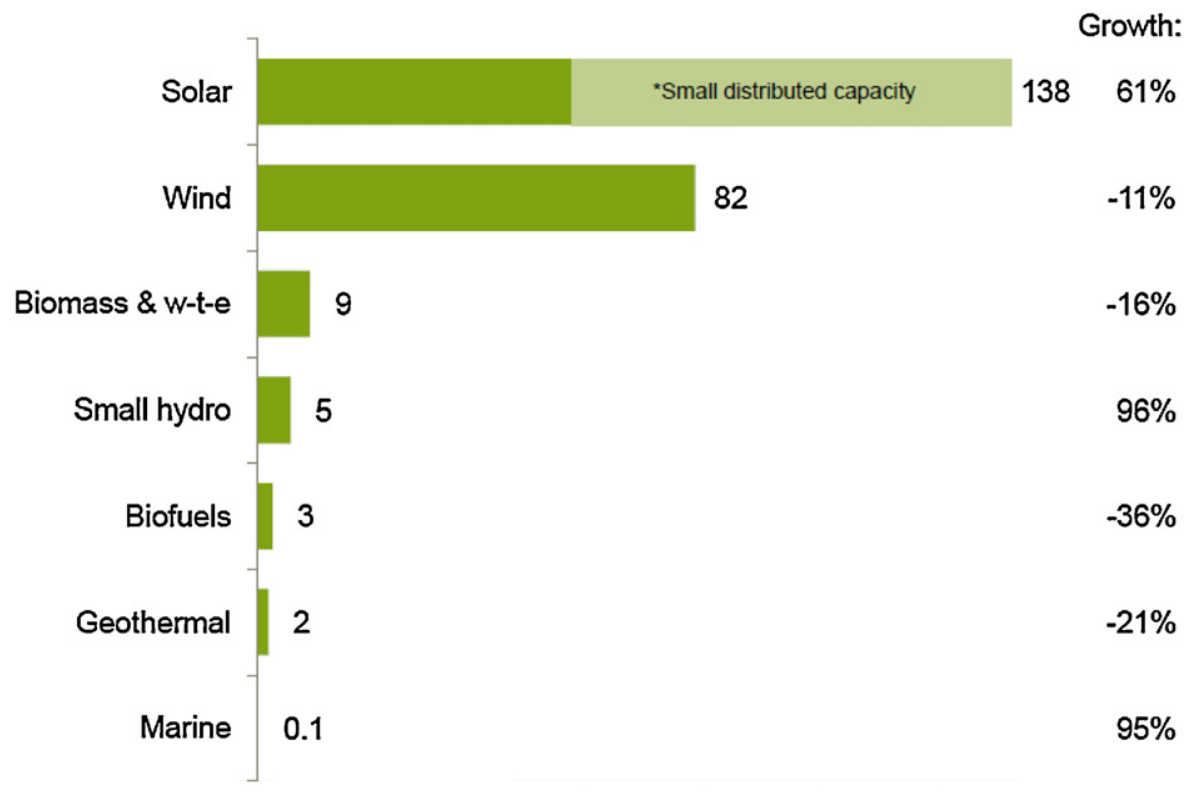

Fig. 10. Asset finance of renewable energy assets and small distributed capacity by technology, 2011 (\$billion) and growth on 2010 (Frankfurt School, 2012: 18).

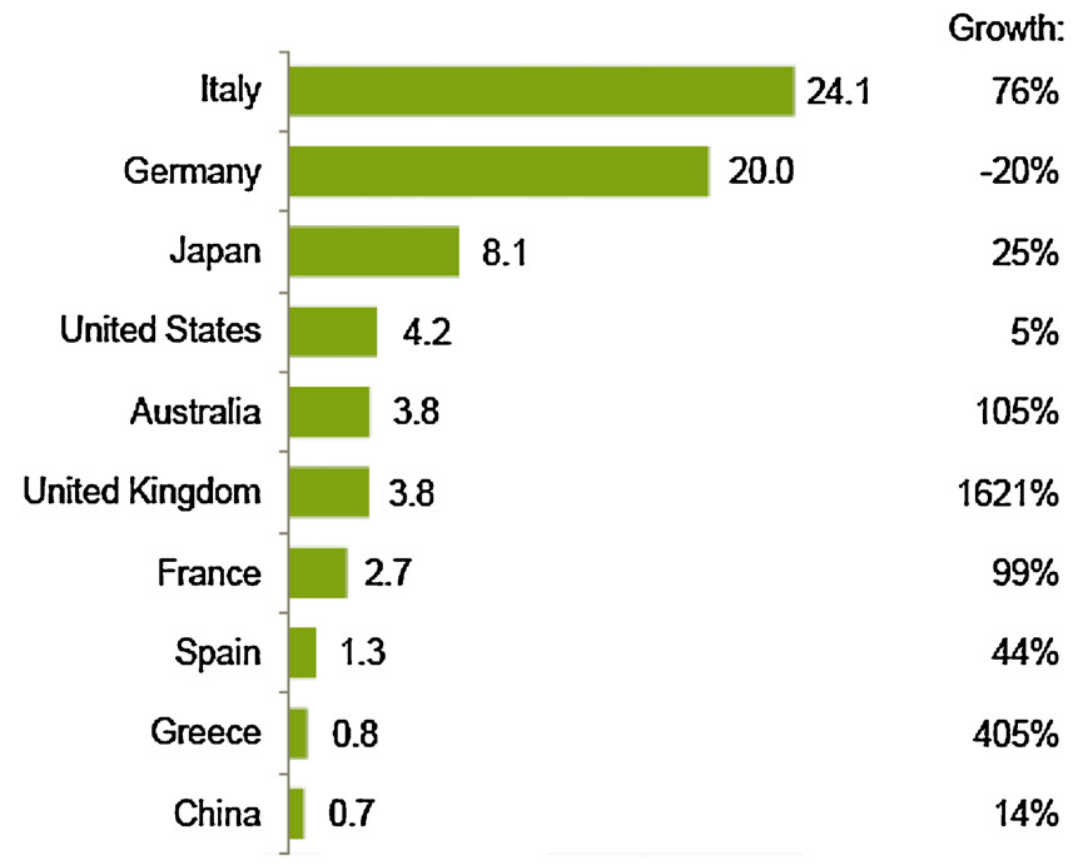

Fig. 11. Small distributed capacity investment by country, 2011 and growth on 2010, \$billion (Frankfurt School, 2012: 51). 
Growth:

$-36 \%+12 \%, 3 \%$ 26\% $15 \%, 32 \%,-16 \%$

10

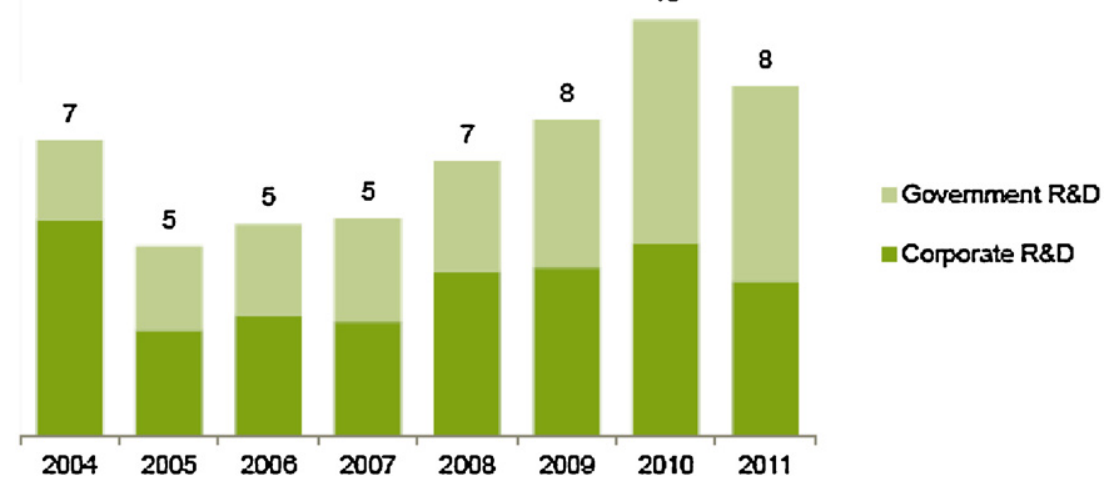

Fig. 12. Global R\&D investment in renewable energy, \$billion (Frankfurt School, 2012: 64).

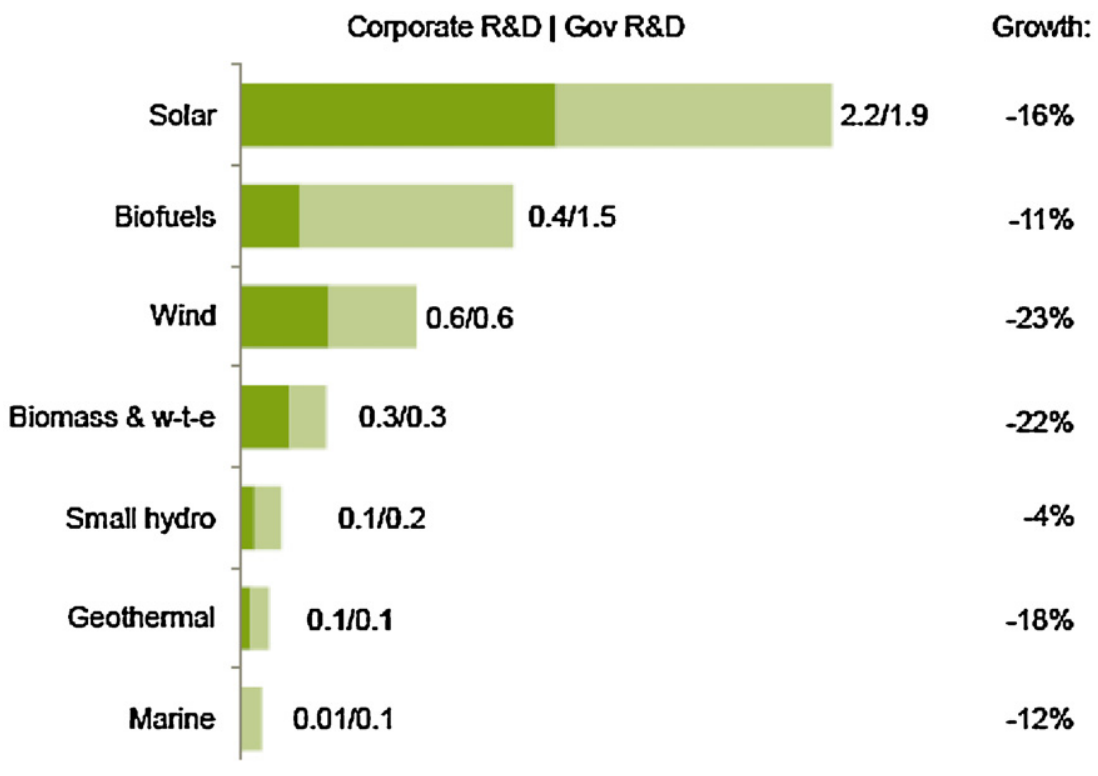

Fig. 13. Global R\&D investment by renewable technology, \$billion (Frankfurt School, 2012: 65).

metabolism of venture capital" (Yergin, 2011: 559). This quote provides further background to the shift in VC towards safer innovations that are closer to market.

Based on these investment data I propose some conclusions and words of caution.

(1) The growth in asset finance and small distributed capacity (Fig. 8) suggests that some renewable energy technologies are moving from the pre-development phase into the take-off phase (because both investment categories relate to concrete deployment).

(2) The financial-economic crisis initially had a positive influence on the sustainability transition through the green stimulus measures, which stimulated global investments in renewable energy 


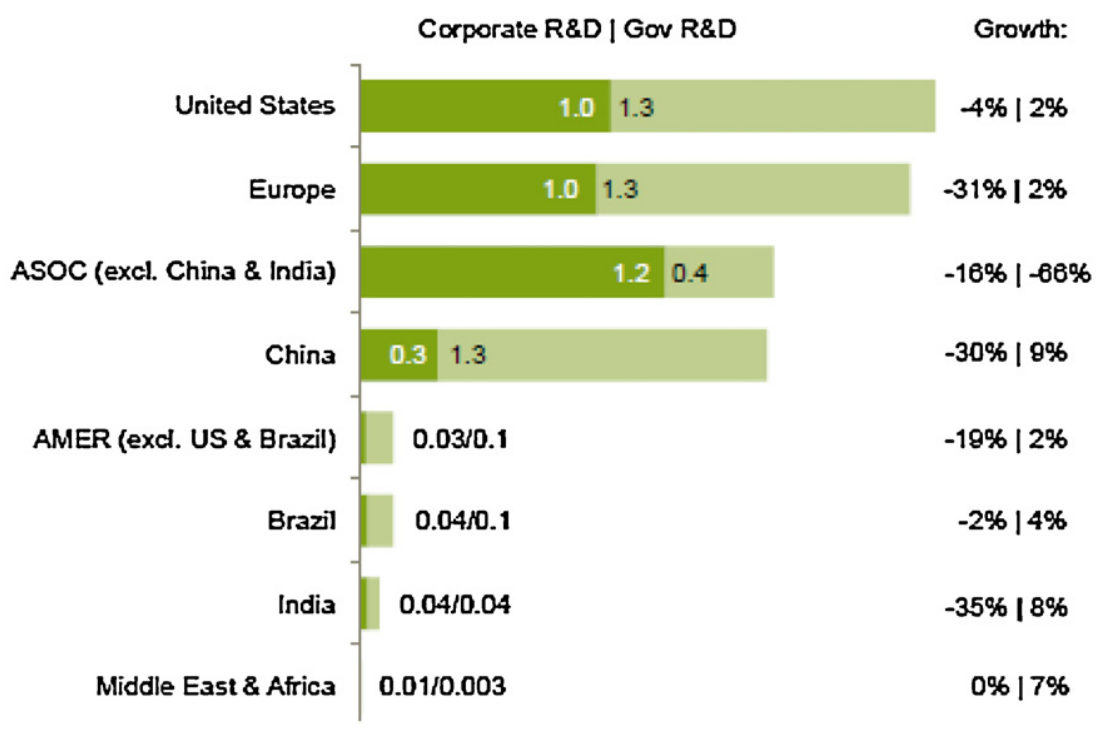

Fig. 14. Corporate and government R\&D investment in renewable energy by region, \$billion in 2011, and growth on 2010 (Frankfurt School, 2012: 65).

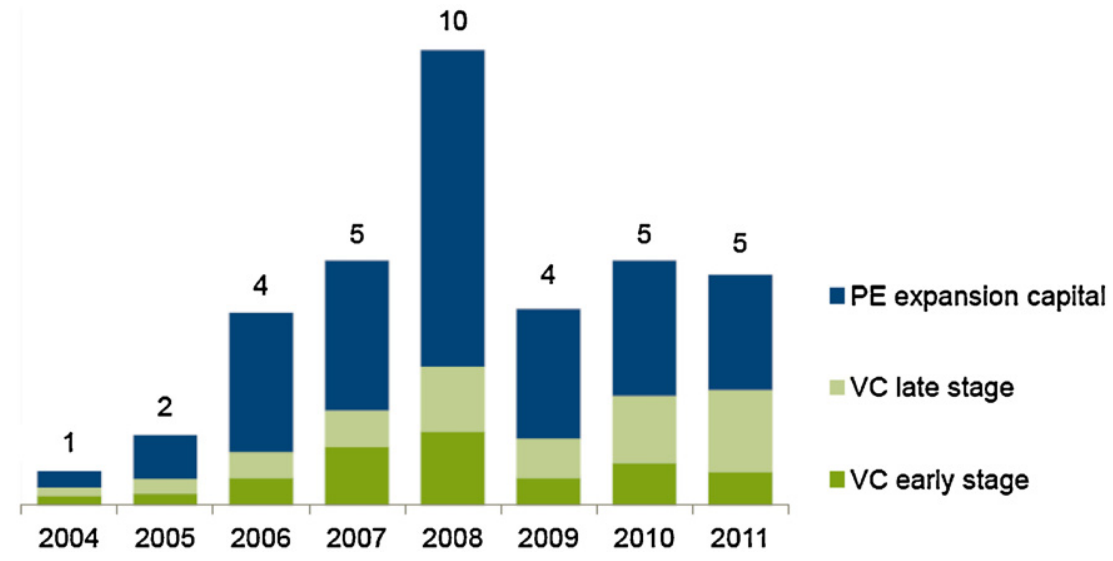

Fig. 15. VC/PE new investment in renewable energy by stage ( $\$$ billion) (Frankfurt School, 2012: 60).

(and other green options). But these green stimulus measures are now coming to an end, leading to steep declines in government spending in Korea, Japan, and other countries, as the financial-economic crisis begins to bite through austerity programmes.

(3) The overall increase in 2011 was in a large part due to rising US investments (Table 4) in utilityscale projects (stimulated by various incentive programmes) and a boom in small-scale PV in Italy and Germany (Fig. 11), stimulated by feed-in tariffs that were generous in relation to falling PVcosts. Because both developments benefited from the impending expiry of subsidy programmes, investments may substantially decrease in 2012, as first quarter results seem to suggest (Fig. 16).

(4) The green growth discourse in Western countries is hindered by cheap Chinese competition, which caused over-capacity, tumbling prices, and bankruptcy or job reductions for many Western wind and solar companies. The industrial shake-out and job losses led politicians to criticize the use of Western government subsidies (for renewable energy) to stimulate Chinese industries. These 


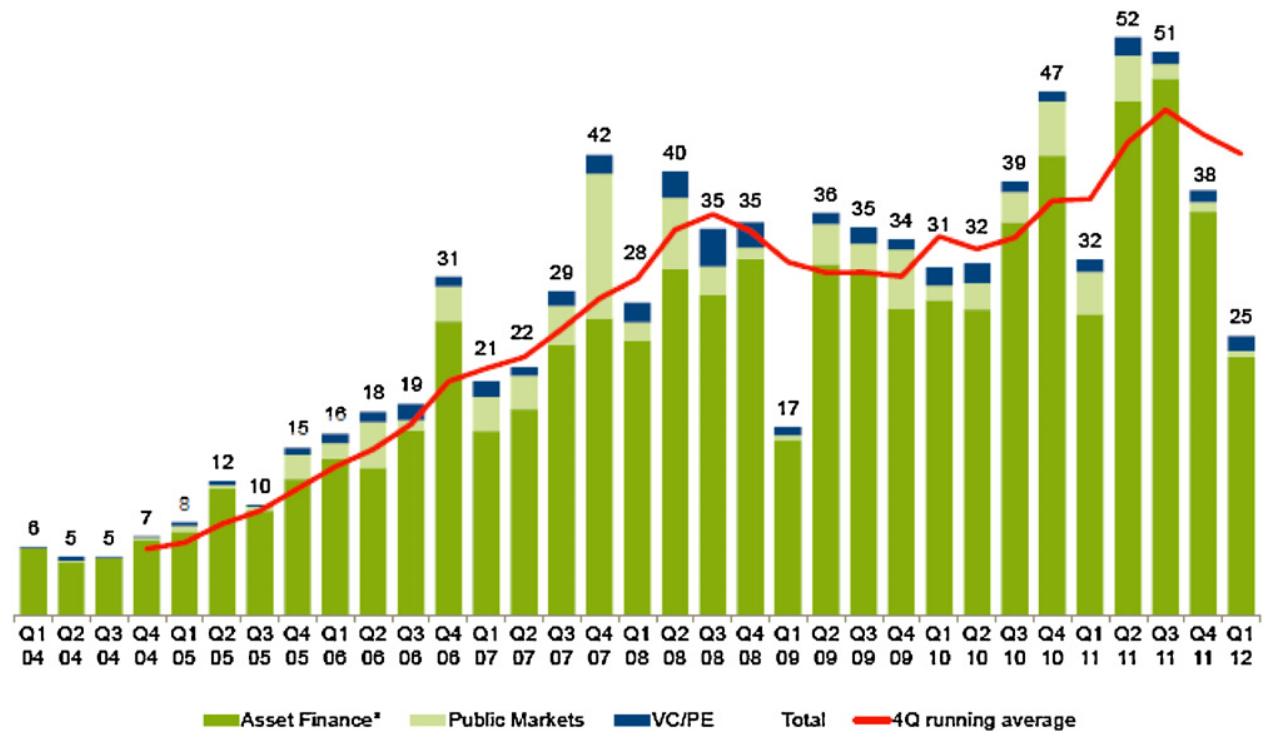

Fig. 16. Quarterly trend in renewable energy investments \$billion (Frankfurt School, 2012: 19).

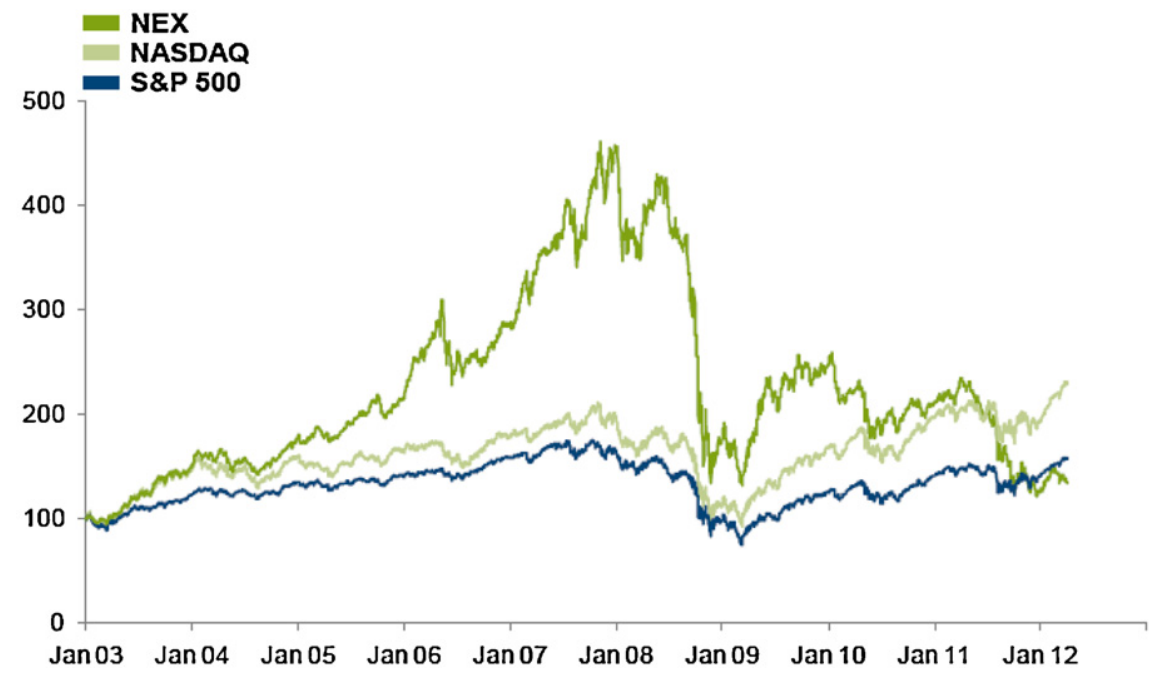

Fig. 17. Performance of renewable energy stocks (NEX) compared to other indices (Frankfurt School, 2012: 55).

problems also contributed to clean energy shares losing three quarters of their value between November 2007 and May 2012. In 2011, the New Energy Global Innovation Index (NEX) slumped by $40 \%$ (Fig. 17), signalling decreasing investor confidence in public equity markets.

Another major threat for investments in renewables is the shale gas revolution, which led the International Energy Agency (2011) to predict a "golden age for natural gas". Helm (2011a) warns that shale gas is a potential game changer: "reserves in the US are now estimated to be sufficient to produce gas for 100 years at current consumption rates. World gas reserves have doubled in the last year. Companies have been quick to react: more than $£ 100$ billion has been spent on shale gas options in the first half of 2010 in the US and Europe" (p. 76). In a recent report, the IEA (2012) suggests that global gas demand may rise by more than 50\% between 2010 and 2035, outstripping 


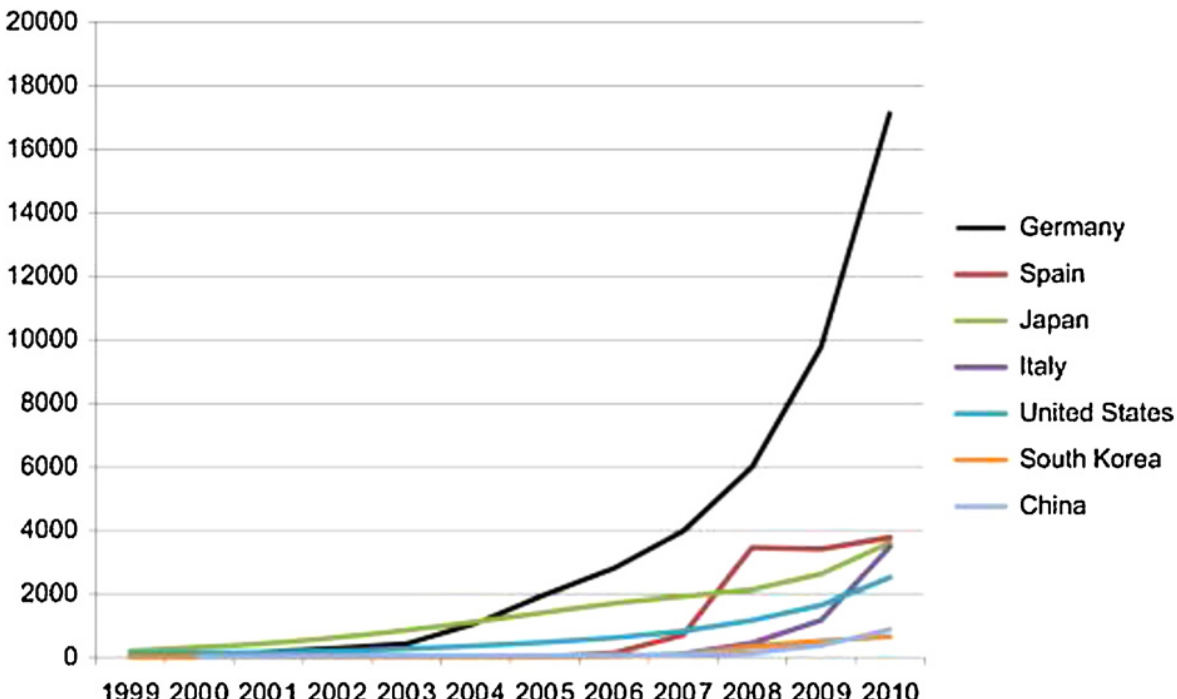

Fig. 18. Cumulative installed solar PV capacity, selected countries, 1999-2010 (MW) (IEA, 2010).

the growth in renewables. The rise of natural gas (mainly shale) may be a double-edged sword. On the one hand, a transition from coal to natural gas (in the US and China) may substantially reduce $\mathrm{CO}_{2}$ emissions. On the other hand, the increase in gas may hinder the progress of renewable energy (Eilperin, 2012) and possibly kill off the recent investment wave (which would damage investor confidence for many years to come).

(5) Although renewable energy investments have been increasing in recent years (Fig. 8), I note two cautions. The first caution is that solar energy, which has received most investment, only makes a small contribution to total primary energy supply (0.2\% in the Euro-area in 2009, Table 2). Germany, which experienced a solar-PV boom in recent years (Fig. 18), is an exception, with solar energy providing about $3 \%$ of electricity in 2011 and $1.5 \%$ of primary energy. In most countries, however, a full transition to solar power still seems a long way off (even though rapidly falling prices make solar-PV more competitive).

With regard to all renewable sources (excluding large hydro) the proportion of global green electricity generated increased from 3.5\% in 2004 to 6\% in 2011 (Fig. 19). The increase is slow (despite large investments) because the existing non-renewable capacity is large and capital intensive (with long operating lives).

The second caution is that more money is (still) being invested in new fossil-fuel generating capacity (coal, gas): $\$ 302$ billion in 2011, compared to $\$ 237$ billion for renewables. Although Fig. 18 shows that the percentage of renewable power in new power capacity has increased to $43.7 \%$, it means that most new capacity is still non-renewable. An additional complication is that renewable power is intermittent and thus requires investments in back-up capacity by non-renewable sources. ${ }^{10}$ The implication of both cautions is that the green energy transition is likely to be relatively slow and gradual. The good news is that it various green niche-innovations seem to have entered a take-off phase (in some countries), although the financial-economic crisis may cause some slow-down.

\footnotetext{
10 This problem can be reduced with a well-connected European electricity network (thanks to a reviewer for pointing this out).
} 


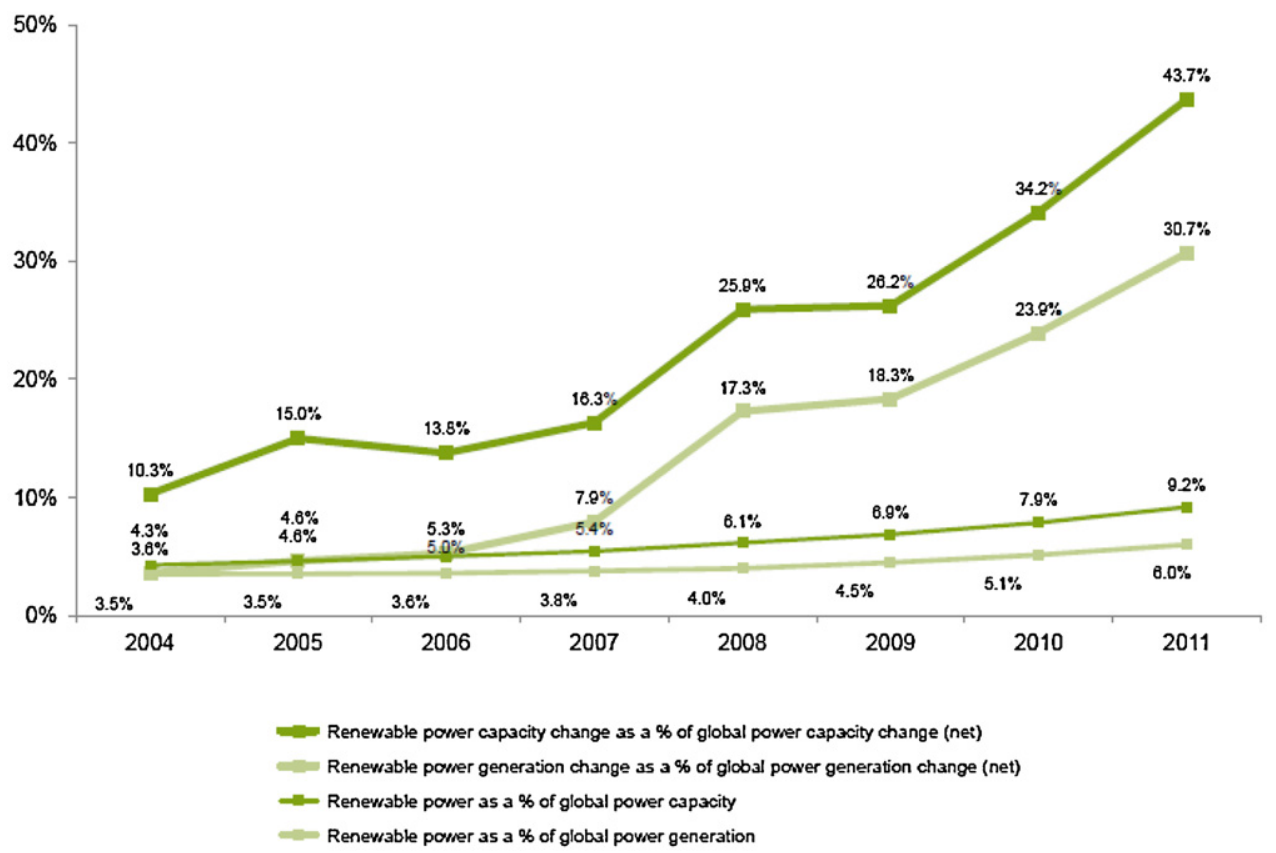

Fig. 19. Renewable power generation and capacity as a proportion of global power (Frankfurt School, 2012: 31).

\subsection{Governance and politics}

There are many goals and targets related to climate change, e.g. the Kyoto protocol, agreed in $1997,{ }^{11}$ the European 20-20-20 targets agreed in $2007,{ }^{12}$ the target to limit climate change to 2degrees, agreed in Copenhagen, 2009, and the UK government's goal of reducing $\mathrm{CO}_{2}$ emissions with $80 \%$ by 2050 . The problem is the realization of these targets, and a track-record of not reaching previously agreed targets, which undermines the credibility of policymakers. In Section 2.2, I already quoted from the UNEP (2011) and OECD (2011) reports about the need for major changes in environmental, economic and innovation policies to bring about sustainability transitions. The IEA's World Energy Outlook (2011) also explicitly warns that: "If bold policy options are not put in place over the next several years, it will become increasingly difficult and costly to meet the goal (...) of limiting a global temperature increase to two degrees Centigrade". Scholars like Giddens (2009: 94) even suggest that wider governance changes may be needed: "Responding to climate change will prompt and require innovation in government itself and in the relation between the state, markets and civil society." Gough and Meadowcroft (2011: 495) also suggest that tinkering with policy instruments may not be enough: "Addressing climate change requires a transformation of production/consumption practices that produce greenhouse emissions; but it will also require a rethink of social welfare institutions built up over the last century".

Unfortunately, most analysts of environmental policy do not think that these changes are currently being made. As one of its key findings for 2011, the Frankfurt School report (2012) notes a "weakening in policy support for renewable energy in many developed countries. This reflected austerity pressures, particularly in Europe, and legislative deadlock in the US Congress" (p. 11). Barbier (2011:66) emphasizes that regime changes are necessary and that: "Without additional policy measures, some of the

\footnotetext{
11 Annex I countries would reduce greenhouse gas emissions by 5.2\% on average for the period 2008-2012, compared to 1990 .

12 By 2020, Europe aims to have reduced greenhouse gas emissions by $20 \%$ compared to 1990 ; reduced energy use by $20 \%$; and reached a share of $20 \%$ renewables in energy consumption.
} 
recent upsurge in global green spending by the G20 (...) will ultimately go to waste: its impact on long-term investment and job creation in green sectors will be restricted by ongoing fossil fuel subsidies and other market distortions, as well as the lack of effective environmental pricing policies and regulations." And with regard to the wider governance changes they propose, Gough and Meadowcroft (2011: 501-502) assess that: "There are at present few signs of the collective agency such a radical shift will require. The current conjuncture of economic crisis and dangerous climate change presents us with an unprecedented problem of system (dis)integration but without a coherent social movement."

If we look at seven policy instruments, ranging from the international to the European to the national (UK) level, it is hard to avoid the impression that climate and energy policies are actually moving in the wrong direction in response to financial-economic pressures (austerity) and declining public attention (Section 3.3).

(1) Since the failed international negotiations in Copenhagen (2009), the world has not been able to develop and accept a successor to the Kyoto protocol. In Durban (November 2011), countries agreed to delay further talks until 2015 , when they will discuss a possible international treaty that could come into force in 2020 . So, international climate negotiations seem to have stalled: "In the period after the Kyoto protocol of 1997, it appeared that countries were on track to raise carbon prices in the major countries of the world, but the pace of climate policies has slowed and even reversed in the last few years. With no replacement for the Kyoto protocol in view as of early 2011, it seems unlikely that there will be strong market incentives to develop low-carbon technologies in the near term" (Nakićenović and Nordhaus, 2011: 570).

(2) During the early crisis years, the international green stimulus packages boosted green options. But many green stimulus packages are coming to an end in 2012, which will lead to a decline in public grants, cheap loans and investments. New packages are unlikely because of austerity measures and because of a change in political discourse: "In 2008-2009, the idea of a 'green recovery' was fashionable among G-20 countries (reducing carbon emissions and creating jobs in one fell swoop). But in the latest phase of the downturn in developed countries, that concept has been aired much less by politicians. In some major countries, including the US and Spain, policies to support renewable energy have become more politically controversial" (Frankfurt School, 2012: 41).

(3) An on-going international problem is the continuation of massive government subsidies for the consumption and production of fossil fuels, which range between $\$ 500$ and $\$ 1000$ billion per year (UNEP, 2011). These subsidies dwarf the support for renewables and signal continued willingness of global governments to prop up fossil fuel industries, despite symbolic expressions of concern about climate change. Uncertainties about the precise amount of subsidies are due to deliberate obfuscation, despite promises of governments to provide more transparency.

(4) At the European level, the Emissions Trading System (ETS) is not (yet) delivering, because the carbon price is relatively low, decreasing, and volatile (Fig. 20), which provides insufficient incentives to invest in radical green options. Based on an empirical evaluation of electricity sectors in seven countries, Schmidt et al. (2012: 38) conclude that that the ETS system "has only limited effects on the rate and direction of corporate RD\&D and adoption".

Although the ETS is currently not working, it is too early to write it off. Perhaps we should see the different phases of ETS as a process of learning about a new policy instrument. This being said, the ETS failures have also given rise to debates about another pricing instrument (carbon taxes), and some countries (such as the UK) have started to implement this. This (on-going) change in instruments creates uncertainty, which itself may hinder sustainability transitions.

(5) Many European governments (Germany, UK, Spain, Italy) have substantially reduced feed-in-tariff subsidies, partly in response to falling technology costs (e.g. PV), and partly to reduce overall government spending.

(6) Government investments in energy R\&D have fallen significantly in the 1980s and 1990s. In the UK, budgets have increased somewhat since 2004, but Fig. 21 suggests that the political commitment to energy is not yet similar to that in the 1970s (when energy crises created a high sense of urgency). In the 2010-2011 fiscal year, the UK government implemented significant cuts in green spending, reducing the budget of the Department of Energy and Climate Change with $£ 85$ million and cutting 


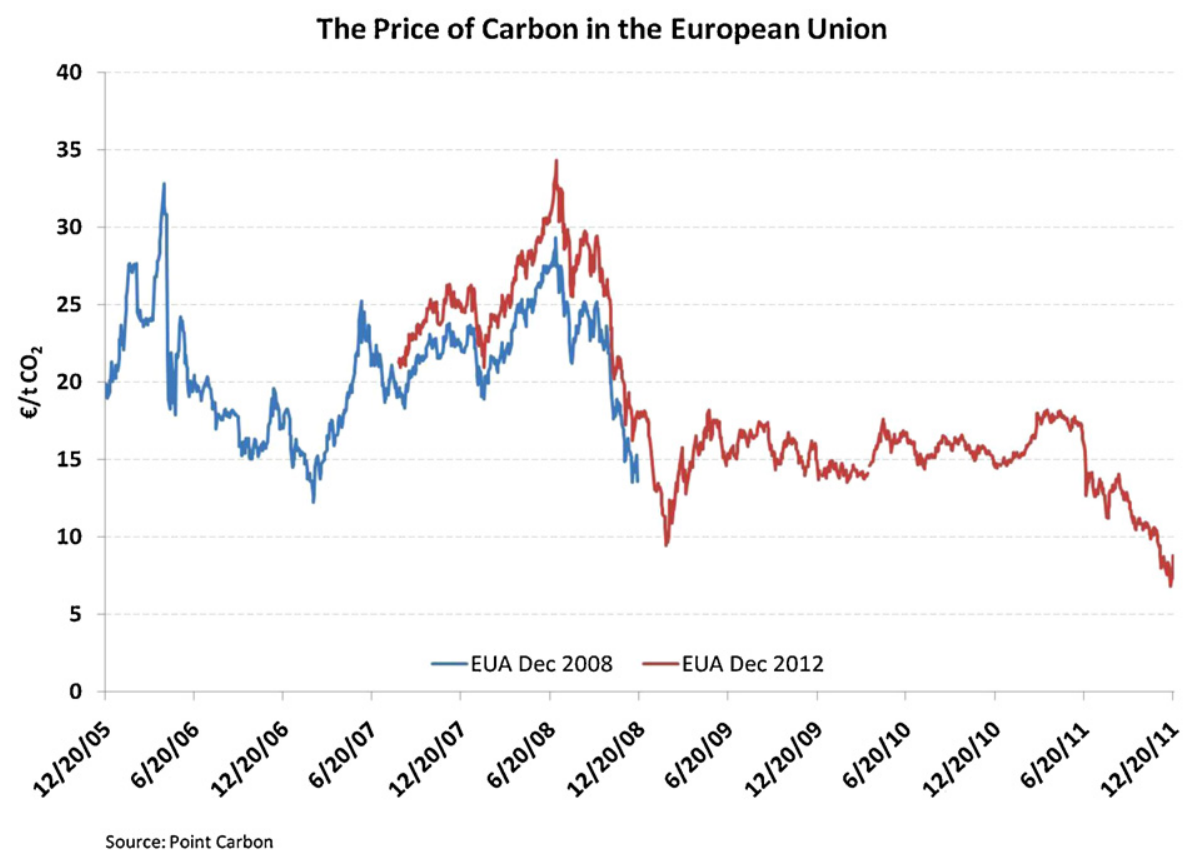

Fig. 20. Carbon price in the European emissions trading scheme. From www.pointcarbon.com (accessed on 09.02.12).

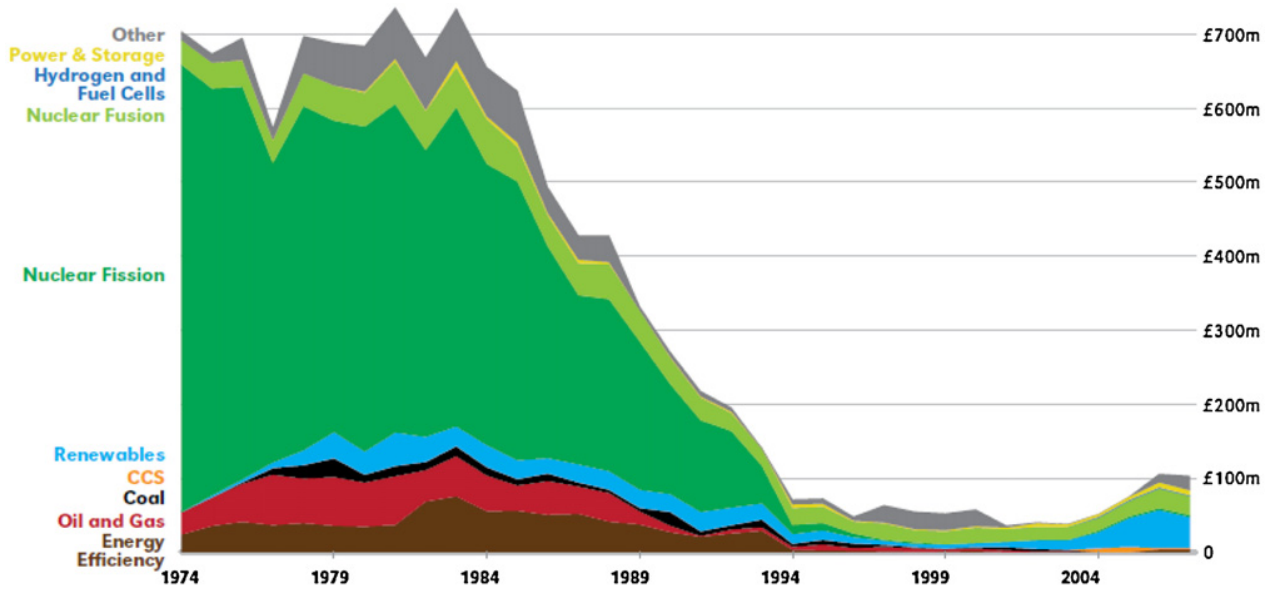

Fig. 21. UK public R\&D into energy (UKERC, 2009: 28).

the budget of the Carbon Trust and Energy Saving Trust by respectively 40\% and 50\% (PIRC, 2011).In Europe, the United States, China and Brazil, government investments in renewable energy R\&D seemed to hold up in 2011 (Fig. 14). But countries like Japan and Korea saw a steep decline, as the stimulus packages were winding down.

(7) The UK government recently introduced another new instrument, The Green Investment Bank, to stimulate the availability of funding for green ventures. But, the government also constrained its 
effectiveness by denying the bank full borrowing powers until 2015 (which limits its operating capital).

Although the story at international, European, and national policy levels is mixed because of the heterogeneity of policy instruments and geographical variety, the general conclusion is that environmental and climate policy instruments are not sufficient to deliver sustainability transitions at the required scale and speed. In fact, some major policy instruments (green stimulus, feed-in tariffs, European emissions trading) seem to be weakening in the last two years of the economic-financial crisis.

A positive development can, however, be identified at the regional and urban level, where quite a few cities are working on green reconfigurations of local systems. In transport, various cities have implemented innovative bus-systems, new cycling facilities, light-rail systems, underground transport, and park-and-ride schemes, e.g. Curitiba, Bogotá, Munich, Freiburg, Zurich, Paris, London, Manchester, Oxford, Singapore, Gothenburg, Amsterdam, Groningen, Copenhagen and Portland. And with regard to climate change, there is the C40 Cities Climate Leadership Group (a network of global megacities) as well as dedicated urban initiatives (e.g. Copenhagen's Plan to be carbon-neutral by 2025) and eco-cities (e.g. Freiburg, Graz). These urban initiatives are enacted by professional actors such as transport planners, urban planners, and civil engineers employed by public works departments. In the words of Thomas Hughes, these professionals can act as 'system builders' on the local level, when they are backed by visionary mayors, citizens and local businesses. Cities not only have professional capabilities, but also financial resources (although usually less than central governments) and a remit to deliver good services and high quality of life. These urban green initiatives are encouraging, firstly because they entail concrete on-the-ground implementation rather than R\&D projects or experiments (which may give rise to expensive hype-disappointment cycles). Secondly, cities may prove to be a new kind of actor that is less constrained by existing regimes and associated dependencies, and has the capabilities and will to drive transitions on-the-ground. ${ }^{13}$ Many urban initiatives started before the financial-economic crisis, in response to local problems, quality of life considerations, or citizen concerns about environmental problems. National austerity programmes may hinder urban initiatives because they affect available capital. But green investment in urban system improvements may form an attractive option for private investors who have been hoarding money in the last few years (see the conclusion section).

I am not an expert with regard to green urban initiatives, but there is an expanding literature that addresses the role of cities in sustainability transitions (e.g. Hodson and Marvin, 2010; Bulkeley et al., 2011; Späth and Rohracher, 2012; Coenen et al., 2012). While I am positively inclined to this literature, I would like to see a bit more attention for: (a) the amount of resources being spent (relative to national governments), (b) are the projects only in city centres or do they cover entire cities, (c) the constitutional 'space' for cities (UK cities seem more constrained than German cities, for example, which relates to broader constitutional issues), (d) what is the scope for small and middle-size cities, which receive less media attention, (e) how do local transport/energy systems fit into larger national systems (infrastructures, regulation, industries)?

\subsection{Public discourse and civil society}

With regard to public discourse, the financial-economic crisis has changed priorities and attention of people. For the UK, a recent opinion poll (May 2012) by Ipsos Mori, one of Britain's leading survey companies, shows that people are most concerned about the economy and unemployment (Fig. 22). Environment and pollution have dropped off the main list of people's concerns.

A longitudinal plotting (Fig. 23) shows that public attention to 'environment/pollution' peaked in 2007, and subsequently declined. A longitudinal plotting of 'the economy' (Fig. 24) shows that public attention rose rapidly with the unfolding of the financial-economic crisis. It is hard to avoid the impression that both issues compete for attention, with economic issues gaining the upper hand.

${ }^{13}$ Some of the above points stem from personal conversations with Fred Steward. 


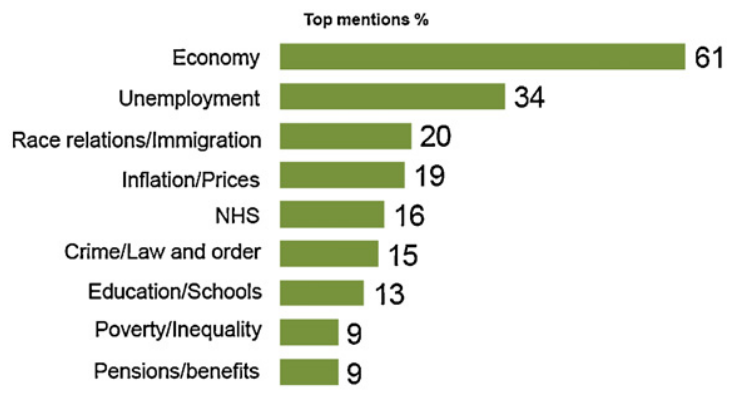

Fig. 22. Ranking of public issues in response to the question: What do you see as the most important issues facing Britain today? (Ipsos Mori, downloaded from: http://www.ipsos-mori.com/researchpublications/researcharchive/2967/ EconomistIpsos-MORI-May-2012-Issues-Index.aspx). (The survey is based on a representative sample of circa 1000 adults, each month interviewed face-to-face in their home.)

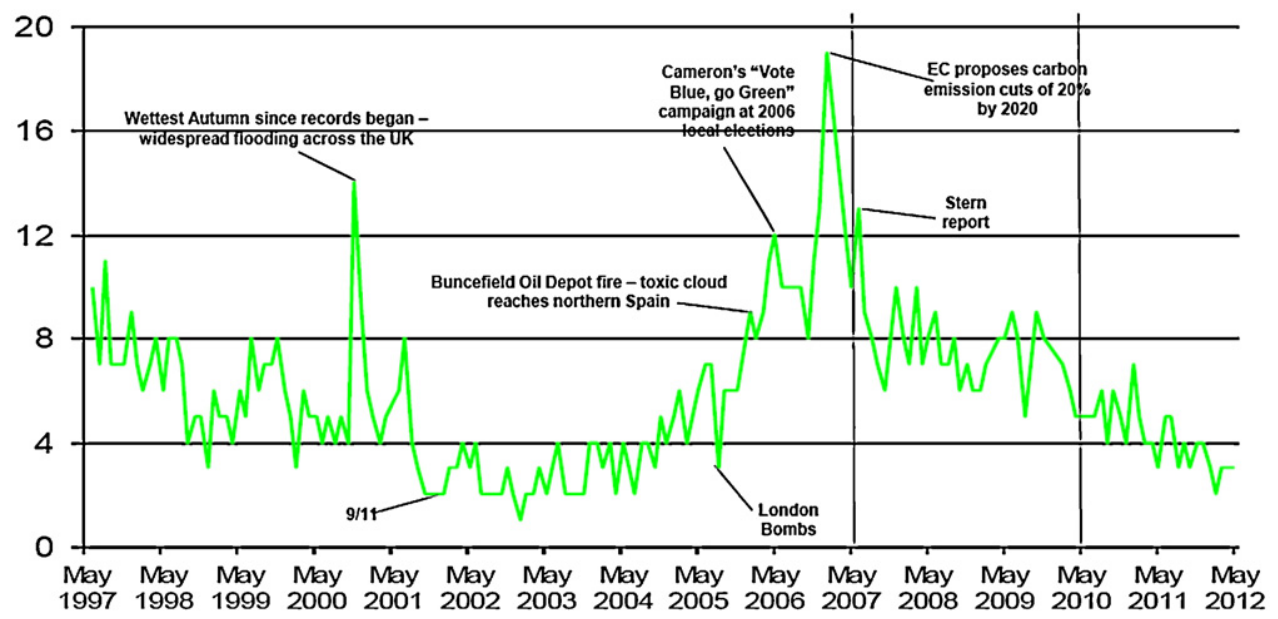

Fig. 23. Percentage of a sample of 1000 adults who rank 'environment/pollution' as one of the most important issues facing Britain (IpsosMori).

A recent public attitudes survey (March 2012) by the UK Department of Energy and Climate Change (DECC) also shows that economic concerns trump concerns about energy and climate change (Table 5).

An analysis of British newspaper counts (Fig. 25) similarly suggests that there was a sharp rise in public attention to climate change from 2004 to 2008-2009, fuelled by events such as hurricane Katrina (2005), Al Gore's movie An Inconvenient Truth (2006), the Stern Review on the Economics of Climate Change (2006), the Fourth IPPC Assessment Report (2007). But in 2010 and 2011 public attention to climate change nose-dived, which is likely to have negative effects on sustainability transitions. ${ }^{14}$

In recent years there not only seems to have been a decline in public attention, but also a shift in the content of (UK) public discourse: "The public debate about energy has started to focus on the costs of the low carbon transition" (Pearson and Watson, 2012: 31). In particular, there are concerns that low-carbon options (offshore wind, interconnection cables, upgrades in electricity grid to deal with the intermittency problem) cause electricity bills to rise. This is not entirely a fair assessment (because the main driver of increasing energy bills are rising global fossil fuel prices), but this public perception nevertheless has an influence on policymakers.

\footnotetext{
${ }^{14}$ It is probably no coincidence that the ambitious UK Climate Change Act (2008) and Low-Carbon Transition Plan (2009) coincided with a peak in public attention.
} 


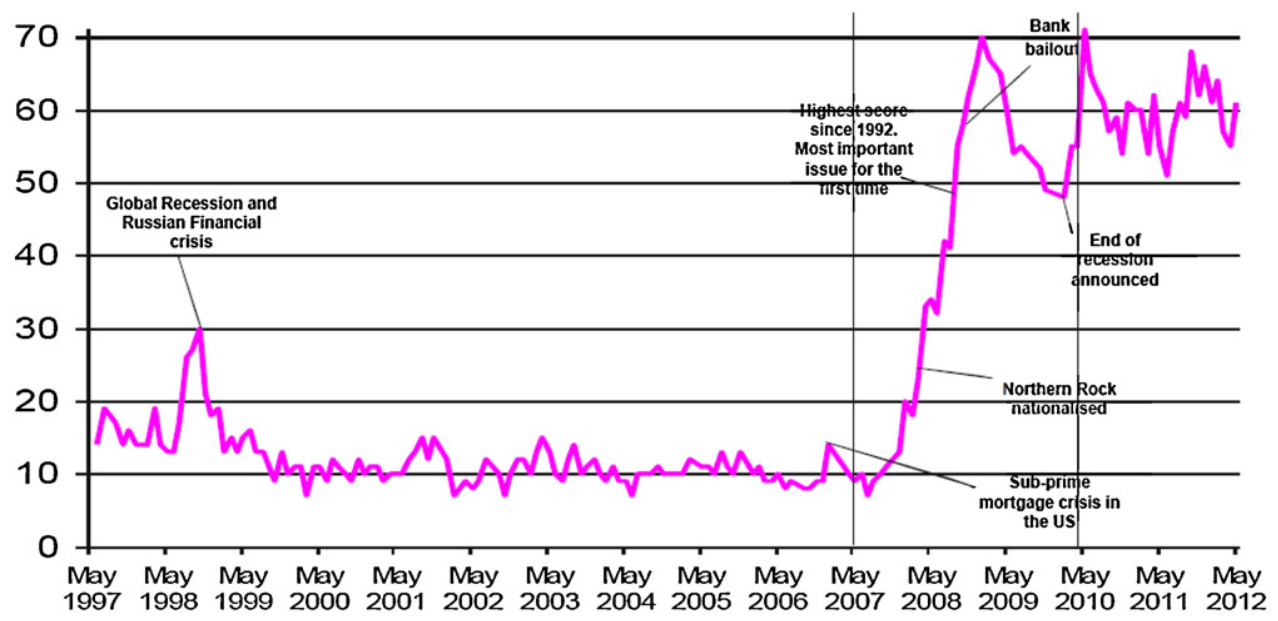

Fig. 24. Percentage of a sample of 1000 adults who rank 'the economy' as one of the most important issues facing Britain (IpsosMori).

Table 5

Public ranking of UK challenges (responses to the question: Which of the areas do you feel represents the biggest/second biggest/third biggest challenge that Britain is facing today? (http://www.decc.gov.uk/en/content/cms/ statistics/public_att/public_att.aspx). ${ }^{\mathrm{a}}$

\begin{tabular}{lcc}
\hline & Top challenge (\%) & $\begin{array}{c}\text { Any mention in top } \\
\text { three challenges (\%) }\end{array}$ \\
\hline Unemployment & 43 & 76 \\
Inflation/rising prices & 13 & 45 \\
National Health Service & 13 & 44 \\
Crime/law and order & 9 & 36 \\
Education & 6 & 25 \\
Level of taxation & 6 & 27 \\
National security/defence & 3 & 10 \\
Energy supply & 3 & 16 \\
Climate change & 2 & 10 \\
Don't know & 2 & 2 \\
\hline
\end{tabular}

a The survey is based on a representative sample of 2121 adults.

There is also positive trend, namely a decentralized groundswell of local sustainability initiatives. Besides the urban initiatives by professional actors, discussed in Section 3.2, there are many grassroots initiatives by activists, social movements and local communities. These initiatives tend to be enacted by volunteers with deep-green normative convictions. One example is Transition Towns, where citizens develop projects in response to climate change and peak oil concerns. A localism agenda is visible in projects around community gardens (to grown your own food), local currencies (to keep money circulating in the community), eco-housing projects, low-carbon lifestyles, community-supported agriculture schemes, farmers markets, and local car-sharing projects. The Transition Town movement started in 2007, and now claims to encompass more than 400 projects in the UK, Ireland, Canada, Australia, US, Italy and Chile. Another, partly related, example concerns community energy projects, in which citizens or neighbourhoods take initiatives to reduce energy use or generate their own energy (with wind turbines, solar panels, biomass digestion). The number of UK projects has increased in recent years in the context of the government's rhetoric on the 'Big Society' and some central funding for local projects (Middlemiss and Parrish, 2010). The momentum of these grassroots projects may not be sufficient, however, to drive a transition. Most projects appear to be small, dependent on the drive of a few people, vulnerable to withdrawal of grants (the recent cuts in feed-in tariffs killed many local projects), and difficult to replicate on a broader scale (because they are tailored to local conditions 


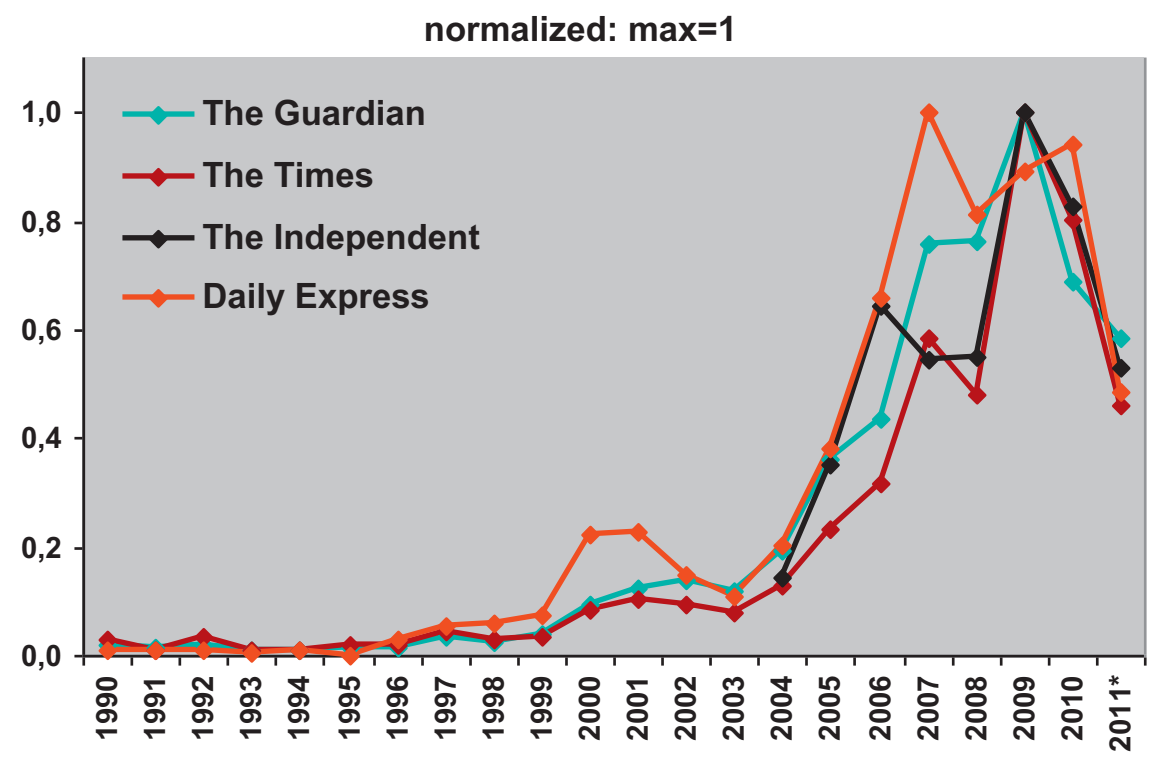

Fig. 25. Yearly number of articles in UK national newspapers containing the word 'climate change'. (The graph is based on data from a keyword search in the digital archives of these newspapers. Duplicated articles were excluded. To facilitate visual comparison between different datasets, we normalized the time series so that 1 refers to the year with the maximum number of counts.)

and because the embedded normativity faces a mis-match with mainstream public orientations). ${ }^{15}$ But these local projects may have positive indirect effects, such as revitalizing a public discourse on sustainability and articulating on-the-ground experiences with concrete implementations that may later prove to be seeds for commercial ventures. ${ }^{16}$

\section{Conclusion}

The article started with four views on the effects of the financial-economic crisis on sustainability transitions, three of which highlighted positive potentials, while the fourth predicted negative impacts. Based on the empirical assessments, I conclude that the effect on public attention has been mainly negative, with the crisis leading to a decline in attention for climate change and sustainability. ${ }^{17}$ The effect on finance was initially positive, because the green growth discourse resulted in major green stimulus programmes. But this positive effect seems to be coming to an end with the winding down of stimulus packages (because of austerity), and recent declines in most other investment categories (Table 3). The decline in feed-in tariffs and other renewable energy support schemes is also likely to result in declining investments in 2012. With regard to governance, the effects seem mainly negative. Although government decisions regarding green stimulus packages (from 2009) were positive, many other trends suggest that austerity and changes in public and political priorities are leading to a weakening of climate and sustainability policies (failure of Copenhagen 2009, no successor of Kyoto, reducing feed-in tariffs and renewable support, failing ETS). Most environmental policy analysts agree that the current policy change is 'too little, too slow'. Although some of the local initiatives (by cities and activists) are pointing in the right direction, my overall assessment is therefore that the early crisis

\footnotetext{
15 Some of these points stem from personal conversations with Adrian Smith.

16 Wind energy, which now is booming business, was also developed by activists, who were frowned upon in the 1970s and 1980 s.

17 For the newspaper count (Fig. 24) there seems to have been a lag-effect of 1-2 years.
} 
years provided a window of opportunity for sustainability transitions, but that this window may now be shrinking.

This slowdown is unlikely to permanently disrupt sustainability transitions, because the underlying problems will not go away (and are likely to get worse). Future accelerations of sustainability transitions may happen in various ways. Zenghelis (2012) suggests that there is plenty of money in the private sector, because firms have been hoarding cash rather than spending it. ${ }^{18}$ So, the problem is not a lack of money, but a lack of investor confidence. He suggests that governments can kick-start the recovery by stimulating green growth and creating confidence about new market opportunities (e.g. via a carbon tax or stringent environmental regulations). So, the first possibility is that bold governments stimulate private spending by creating certainty about future green markets using a mix of policies such as pricing, regulation and institutional reform. While this is an option, Section 3.2 suggests that these policy changes are not yet forthcoming. A second possibility is that city initiatives, mentioned in Section 3.3, provide opportunities for unleashing private investment. Helm (2011b) suggests that urban infrastructures (and national networks) may provide an interesting option for investors in times of uncertainty. The returns for these 10-20 year investments may be somewhat lower, but they are stable and predictable. Possible infrastructures are water and sewerage pipes, waste treatment works, electricity and gas networks, communication networks, and rail networks. Many of these infrastructures suffered from under-investment in recent decades and need upgrading. If these upgrades are linked to broader urban initiatives (e.g. retrofitting old houses, waste management, recycling, public transport), they may accelerate sustainability transitions. Legitimation can come from combinations of 'sustainability' issues and quality of life improvements. A third possibility is that some renewable options (onshore wind, solar-PV) become cost-competitive in the next few years, which enables them to compete with fossil fuel and nuclear options. ${ }^{19}$ When green electricity options reach 'grid parity', economic and technical considerations may further drive the energy transition in a green direction. A fourth possibility is that public attention and concern increase again in a few years' time, which creates pressure on policymakers to take bold actions. Such oscillations are not uncommon in issue-attention cycles (Penna and Geels, 2012). Future increases in public attention may be related to new scientific findings (e.g. accelerated polar melting), shock events (heat waves, hurricanes, flooding) or enhanced activity from social movements. The problem is that waiting a few years may further lock the climate system into unsustainable trajectories. So, one way or another it is likely that the sustainability transition will accelerate again in future years.

In conceptual terms, future research might focus further on the challenges and drivers in the take-off phase in transitions. Section 2.2 suggested that transition research should develop a better understanding of the relationships between public attention and opinion, governance, and business/investment. A simple hypothesis is that a major investment surge requires substantial policy changes, which in turn requires public attention and support (for reasons of legitimacy). Scientific research (e.g. warnings about the speed and impact of climate change) may also play a role in stimulating policymakers to act, but this role is often mediated or reinforced by public attention and opinion. The unfolding crisis, and the eventual acceleration of sustainability transitions, provides fruitful conditions to test and explore these hypotheses in the coming years.

\section{Acknowledgements}

This work has been supported by an ERC grant (No. 204246). I want to thank Bram Verhees for letting me use his data on climate change reporting in British newspapers. And I want to thank a reviewer and Jeroen van den Bergh for their thoughtful and constructive comments on previous versions of this paper.

\footnotetext{
${ }^{18}$ He estimates that the private sector in the US generated surpluses of $\$ 1.2$ trillion in 2009 , \$1.1 trillion in 2010, and \$1.0 trillion in 2011.

19 Between December 2010 and December 2011, PV-modules from China and Taiwan declined in price by almost 50\% (Schleicher-Tappeser, 2012).
} 


\section{References}

Allianz Global Investors, 2010. The Sixth Kondratieff - Long Waves of Prosperity. Allianz Global Investors, Frankfurt.

Ashford, N.A., Hall, R.A., Ashford, R.H., 2012. The crisis in employment and consumer demand: reconciliation with environmental sustainability. Environmental Innovation and Societal Transitions 2 (1), 1-22.

Barbier, E.B., 2010. How is the global green new deal going? Nature 464, 832-833.

Barbier, E.B., 2011. Transaction costs and the transition to environmentally sustainable development. Environmental Innovation and Societal Transitions 1 (1), 58-69.

Blyth, M., 2002. Great Transformations: Economic Ideas and Institutional Change in the Twentieth Century. Cambridge University Press, New York.

Bowen, A., Fankhauser, S., 2011. The green growth narrative: paradigm shift or just spin? Global Environmental Change 21, 1157-1159.

Bradfield-Moody, J., Nogrady, B.T., 2010. The Sixth Wave: How to Succeed in a Resource-Limited World. Vintage Books, Sydney.

Bulkeley, H., Broto, V.C., Hodson, M., Marvin, S. (Eds.), 2011. Cities and Low Carbon Transitions. Routledge, New York.

Coenen, L., Benneworth, P., Truffer, B., 2012. Towards a spatial perspective on sustainability transitions. Research Policy 41 (6), 968-979.

Burnstein, P., 2003. The impact of public opinion on public policy: a review and an agenda. Political Research Quarterly 56 , 29-40.

Downs, A., 1972. Up and down with ecology: the issue attention cycle. The Public Interest 28, 35-50.

Edenhofer, O., Stern, N., 2009. Towards a Global Green Recovery: Recommendations for Immediate G-20 Action. Potsdam Institute for Climate Change, Potsdam.

Eilperin, J., 2012. Why the clean tech boom went bust. Wired Magazine, February 2012.

Frankfurt School of Finance and Management gGmbH (in collaboration with Bloomberg New Energy Finance), 2012. Global Trends in Renewable Energy Investment 2012.

Freeman, C., Perez, C., 1988. Structural crisis of adjustment, business cycles and investment behaviour. In: Dosi, G., Freeman, C., Nelson, R., Silverberg, G., Soete, L. (Eds.), Technical Change and Economic Theory. Pinter, London, pp. 38-66.

Geels, F.W., 2002. Technological transitions as evolutionary reconfiguration processes: a multi-level perspective and a casestudy. Research Policy 31 (8-9), 1257-1274.

Geels, F.W., Schot, J.W., 2007. Typology of sociotechnical transition pathways. Research Policy 36 (3), 399-417.

Geels, F.W., Verhees, B., 2011. Cultural legitimacy and framing struggles in innovation journeys: a cultural-performative perspective and a case study of Dutch nuclear energy (1945-1986). Technological Forecasting and Social Change 78 (6), 910-930.

Geels, F.W., Kemp, R., Dudley, G., Lyons, G. (Eds.), 2012. Automobility in Transition? A Socio-Technical Analysis of Sustainable Transport. Routledge, New York.

Giddens, A., 2009. The Politics of Climate Change. Polity Press, Cambridge, UK.

Gore, C., 2010. The global recession of 2009 in a long-term development perspective. Journal of International Development 22 , 714-738.

Gough, I., 2010. Economic crisis, climate change and the future of the welfare state. Twenty-First Century Society 5, 51-64.

Gough, I., Meadowcroft, J., 2011. Decarbonising the welfare state. In: Dryzek, J., Norgaard, R., Schlosberg, D. (Eds.), The Oxford Handbook of Climate Change and Society. Oxford University Press, Oxford, pp. 490-503.

Hall, P.A., 1993. Policy paradigms, social learning and the state: the case of economic policy making in Britain. Comparative Politics 25 (3), 275-296.

Helm, D., 2011a. Peak oil and energy policy-a critique. Oxford Review of Economic Policy 27 (1), 68-91.

Helm, D., 2011b. The sustainable borders of the state. Oxford Review of Economic Policy 26 (2), 182-196.

Hilgartner, S., Bosk, C.L., 1988. The rise and fall of social problems: a public arenas model. American Journal of Sociology 94 (1), 53-78.

Hodson, M., Marvin, S., 2010. Can cities shape socio-technical transitions and how would we know if they were? Research Policy 39 (4), 477-485.

IEA, 2010. Trends in photovoltaic applications. Report IEA-PVPS T1-19:2010.

International Energy Agency, 2011. World Energy Outlook.

IEA, 2012. Golden Rules for a Golden Age of Gas.

Jackson, T., Victor, P., 2011. Productivity and work in the 'green economy': some theoretical reflections and empirical tests. Environmental Innovation and Societal Transitions 1 (1), 101-108.

Levy, D.L., Newell, P.J., 2000. Oceans apart? Business responses to the environment in Europe and North America. Environment $42(9), 8-20$

Markard, J., Raven, R., Truffer, B., 2012. Sustainability transitions: an emerging field of research and its prospects. Research Policy 41 (6), 955-967.

Meadowcroft, J., 2005. From welfare state to ecostate. In: Barry, J., Eckersley, R. (Eds.), The State and the Global Ecological Crisis. MIT Press, Cambridge, MA, pp. 3-23.

Meadowcroft, J., 2011. Engaging with the politics of sustainability transitions. Environmental Innovation and Societal Transitions 1 (1), 70-75.

Middlemiss, L., Parrish, B.D., 2010. Building capacity for low-carbon communities: the role of grassroots initiatives. Energy Policy 38 (12), 7559-7566.

Nakićenović, N., Nordhaus, W., 2011. Editors' introduction: the economics of technologies to combat global warming. Energy Economics 33, 565-571.

Newig, J., 2004. Public attention, political action: the example of environmental regulation. Rationality and Society 16, 149-190.

Nykvist, B., Whitmarsh, L., 2008. A multi-level analysis of sustainable mobility transitions: niche developments in the UK and Sweden. Technological Forecasting and Social Change 75 (9), 1373-1387.

OECD, 2011. Towards Green Growth: A Summary for Policy Makers. Paris. 
Oosterveer, P., Spaargaren, G., 2012. Green consumption practices and emerging sustainable food regimes. In: Spaargaren, G., Oosterveer, P., Loeber, A. (Eds.), Food Practices in Transition; Changing Food Consumption, Retail and Production in the Age of Reflexive Modernity. Routledge, New York, pp. 131-152.

Pearson, P., Watson, J., 2012. UK Energy Policy 1980-2010: A History and Lessons to be Learnt. Parliamentary Group for Energy Studies, London.

Penna, C.C.R., Geels, F.W., 2012. Multi-dimensional struggles in the greening of industry: a dialectic issue lifecycle model and case study. Technological Forecasting and Social Change 79 (6), 999-1020.

Perez, C., 2002. Technological Revolutions and Financial Capital: The Dynamics of Bubbles and Golden Ages. Edward Elgar, Cheltenham.

Perez, C., 2009. The double bubble at the turn of the century: technological roots and structural implications. Cambridge Journal of Economics 33 (4), 779-805.

PIRC (Public Interest Research Centre), 2011. The Green Investment Gap: An Audit of Green Investment in the UK, Powys, Wales.

Pierson, P., 2000. Increasing returns, path dependence, and the study of politics. American Political Science Review 94 (2), 251-267.

Rivoli, P., Waddock, S., 2011. “First They Ignore You...”: the time-context dynamic and corporate responsibility. California Management Review 53, 87-104.

Rockström, J., et al., 2009. A safe operating space for humanity. Nature 641, 472-475.

Scrase, I., MacKerron, G. (Eds.), 2009. Energy for the Future: A New Agenda. Palgrave MacMillan, New York.

Schleicher-Tappeser, R., 2012. How renewables will change electricity markets in the next five years. Energy Policy 48, 64-75.

Schmidt, T.S., Schneider, M., Rogge, K.S., Schuetz, M.J.A., Hoffmann, V.H., 2012. The effects of climate change policy on the rate and direction of innovation: a survey of the EU ETS and the electricity sector. Environmental Innovation and Societal Transitions 2 (1), 23-48.

Smith, A., Jan-Peter Voß, J.-P., Grin, J., 2010. Innovation studies and sustainability transitions: the allure of a multi-level perspective and its challenges. Research Policy 39 (4), 435-448.

Späth, P., Rohracher, H., 2012. Local demonstrations for global transitions: dynamics across governance levels fostering sociotechnical regime change towards sustainability. European Planning Studies 20 (3), 461-479.

UKERC (UK Energy Research Centre), 2009. Making the transition to a secure and low-carbon energy system. Synthesis report. UNEP, 2009. Global Green New Deal: Policy Brief. United Nations Environment Programme, Nairobi, Kenya.

UNEP, 2011. Towards a Green Economy: Pathways to Sustainable Development and Poverty Eradication; A Synthesis for Policy Makers. United Nations Environment Programme, Nairobi, Kenya.

Van Bree, B., Verbong, G.P.J., Kramer, G.J., 2010. A multi-level perspective on the introduction of hydrogen and battery-electric vehicles. Technological Forecasting \& Social Change 77 (4), 529-540.

Van den Bergh,J.C.J.M., Truffer, B., Kallis, G., 2011. Environmental innovation and societal transitions: introduction and overview. Environmental Innovation and Societal Transitions 1 (1), 1-23.

Walker, W., 2000. Entrapment in large technology systems: institutional commitments and power relations. Research Policy $29(7-8), 833-846$.

Wray, L.R., 2009. The rise and fall of money manager capitalism: a Minskian approach. Cambridge Journal of Economics 33 (4), 807-828.

Yergin, D., 2011. The Quest: Energy, Security and the Remaking of the Modern World. Penguin Press, New York.

Zenghelis, D., 2012. A Strategy for Restoring Confidence and Economic Growth Through Green Investment and Innovation. Policy Brief. Grantham Institute, London School of Economics, London. 